\title{
1 Human eye conditions: insights from the fly eye
}

2

3 Pedro Gasparr, ${ }^{1, *}$, Isabel Almudi ${ }^{2, *}$, Maria D. S. Nunes ${ }^{1}$ and Alistair P. McGregor ${ }^{1}$

4

5

$6{ }^{1}$ Department of Biological and Medical Sciences, Oxford Brookes University, Gipsy Lane,

7 Oxford UK OX3 OBP.

$8{ }^{2}$ Centro Andaluz de Biología del Desarrollo, CSIC/ Universidad Pablo de Olavide,

9 Carretera de Utrera Km1, 41013 Sevilla, Spain.

10

$11{ }^{*}$ Contributed equally

12 


\section{Abstract}

2 The fruit fly Drosophila melanogaster has served as an excellent model to study and

3 understand the genetics of many human diseases from cancer to neurodegeneration.

4 Studying the regulation of growth, specification and differentiation of the compound eyes

5 of this fly, in particular, have provided key insights into a wide range of diseases. Here we

6 review the regulation of the development of fly eyes in light of shared aspects with human

7 eye development. We also show how understanding conserved regulatory pathways in

8 eye development together with the application of tools for genetic screening and functional

9 analysis make Drosophila a powerful model to diagnose and characterise the genetics

10 underlying many human eye conditions, such as aniridia and retinitis pigmentosa. This

11 further emphasises the importance and vast potential of basic research to underpin

12 applied research including identifying and treating the genetic basis of human diseases. 


\section{Introduction}

2 The sequencing of the genome of the fruit fly Drosophila melanogaster in 2000 (Adams et

3 al. 2000; Myers et al. 2000; Rubin and Lewis 2000) and subsequent comparative genomic

4 studies showed that approximately $70 \%$ of human disease-associated genes have a single

5 Drosophila homolog, and that there is even greater enrichment for genes that cause lethality in Drosophila that are represented by multiple homologues in humans (Reiter et al. 2001; Yamamoto et al. 2014). This highlights the relevance of this model organism to study the function of conserved genes and their effect in human disease (Wangler et al.

9 2015). Indeed, studies of the genetic regulation of Drosophila development over the last 30 years have provided many crucial insights into the genetic basis and progression of a wide range of human conditions from cancer to neurodegeneration and aging (Burke et al. 2017; Kreipke et al. 2017; Michno et al. 2005; Sen and Cox 2017; Sonoshita and Cagan 2017).

The compound eye of Drosophila in particular has proven to be an excellent model

15 for many diseases despite the noticeable anatomical differences between insect and vertebrate eyes (Fig. 1; Table 1). The Drosophila eye is constituted of a regular array of several hundred individual light-sensing hexagonal structures called ommatidia (Cagan 2009; Hilbrant et al. 2014; Kumar 2012; Posnien et al. 2012), each of which transmits a single image to the brain that must then project it onto one spherical retinal image (Land 2005) (Fig. 1). In contrast, the human "camera" eye is a globular structure with a single lens leading to the formation of a single image (Fig. 1). As a consequence, humans have a much narrower field-of-view than fruit flies (Borst 2009). However, the human eye has thousands of sensory cells (rods and cones) packed tightly into its retina (Jonas et al. 1992) while each Drosophila ommatidia only has eight photoreceptors and 12 accessory cells (Treisman 2013), a difference that contributes to the larger spatial resolution and 
1 insect and vertebrate eyes are made up of a lens to focus light, a neural retina with

2 photoreceptors to sense the light and a pigmented epithelium to protect photoreceptor

3 signalling from scattered or diffracted light (Charlton-Perkins et al. 2011; Sanes and

4 Zipursky 2010) (Fig. 1). More importantly, however, decades of research has revealed that

5 the development of Drosophila eyes is regulated by conserved genetic pathways that are

6 conserved between flies and humans, and consequently studies of Drosophila have taught

7 us much about human eyes (Gehring 2005; Halder et al. 1995; Kumar and Moses 2001;

8 Vopalensky and Kozmik 2009; Wawersik and Maas 2000). In this review we focus on how

9 research on the genetic regulation of Drosophila eye development has informed our

10 understanding of many eye conditions in humans (Table 1), highlighting the power and

11 potential of research on fly eyes to better understand and potentially treat human

12 conditions.

14 Eye development

15 Master regulators of invertebrate and vertebrate eye development

16 The Drosophila eye develops from an evagination of the embryonic neuroectoderm to form

17 two epithelial sacs, the so-called eye-antenna imaginal disc (Casares and Almudi 2016;

18 Green et al. 1993; Younossi-Hartenstein et al. 1993) (Figs 1 and 2). This region is

19 characterised by the early expression of the conserved transcription factors, orthodenticle

20 (otd)/Otx and twin of eyeless (toy), and later by expression of the Pax6 homologue eyeless

21 (ey) in the posterior region of the epithelial sac, which will give rise to the eye, ocelli, and

22 head capsule and expression of Cut in the anterior region, which will mostly give rise to the 23 antenna and maxillary palps (Czerny et al. 1999; Kenyon et al. 2003) (Fig. 2).

24 Much like in Drosophila, vertebrate eye development is centred on the activity of 25 master control genes, namely the Pax6 gene. Vertebrate Pax6 genes encode two 26 alternatively spliced variants that differ in the presence of exon 5a. In contrast, Drosophila 
1 Pax6 and Pax6(5a) homologues arose as separate loci from a relatively recent gene

2 duplication event (Aldaz et al. 2003; Jun et al. 1998). Like in vertebrates, the two

3 Drosophila Pax6 genes, ey and toy (Czerny et al. 1999; Quiring et al. 1994), and two

4 Pax6(5a) genes, eyegone (eyg) and twin-of-eyegone (toe) (Jang et al. 2003; Jun et al.

5 1998) have distinct roles in eye development. ey and toy promote primarily retinal

6 specification, whereas eyg mainly promotes cell proliferation (Chao 2004; Dominguez et

7 al. 2004). Each $\operatorname{Pax6/Pax6(a)}$ orthologue also acts through distinct transcriptional

8 mechanisms, with Ey acting as a transcriptional activator, while Eyg seems to act as a

9 transcriptional repressor (Chao 2004; Dominguez et al. 2004; Punzo 2004; Punzo et al.

10 2001; Yao and Sun 2005).

11 Based on its sufficiency for eye development in Drosophila and vertebrates, it was

12 originally proposed that Pax6 functions at the highest level of a hierarchy of genes whose

13 sequential expression lead to eye development (Gehring 1996). Indeed, three core

14 members of this postulated hierarchy: eya (EYA1, EYA2, EYA3), sine oculis (so, SIX1,

$15 \mathrm{SIX} 2$ and SIX3), and dac (DACH1) have been identified in Drosophila and vertebrates, all

16 sharing similar temporal expression patterns during eye development (Bonini et al. 1997;

17 Chen et al. 1997; Pignoni et al. 1997; Shen and Mardon 1997; Treisman 1999; Zuber

18 2003). Rather than acting in a simple linear pathway, positive transcriptional feedback

19 organizes these master control genes into an interconnected network (Desplan 1997). This

20 regulatory structure appears critical to induce retinal tissue as evidenced by mis-

21 expression experiments where core genes fail to induce ectopic eyes if any of the other

22 critical factors is absent (Bonini et al. 1997). Positive transcriptional feedback seems

23 relevant in this case for activating a second, independently regulated phase of gene

24 expression, as many of these genes indeed function at several stages of eye

25 development. For instance, ey, eya and so are critical for growth of the eye primordium

26 and initiation of differentiation (Bonini et al. 1993; Cheyette et al. 1994; Halder et al. 1998; 
1 Jang et al. 2003; Mardon et al. 1994; Pignoni et al. 1997), while eya and so are then also

2 required for progression of the MF and photoreceptor differentiation (Pignoni et al. 1997),

3 and ey is needed for rhodopsin gene expression (Papatsenko et al. 2001; Sheng et al. 4 1997).

\section{Cellular differentiation}

7 The differentiation of the cells that form the ommatidia in Drosophila is a sequential

8 process. A morphogenetic wave, designated as the morphogenetic furrow (MF, Figs 1 and

9 2), sweeps across the epithelium from the most posterior region towards the anterior

10 promoting the recruitment and differentiation of the different types of cells that constitute

11 the ommatidium (reviewed in Kumar 2011; Lee and Treisman 2002). During the first larval

12 stages of Drosophila, the epithelial cells are undifferentiated progenitor cells that

13 proliferate continuously due to the combined activity of the genes ey, homothorax (hth),

14 toy, teashirt (tsh), tiptop and yorkie (yki) (Figs 1 and 2) (Bessa et al. 2009; Bessa and

15 Casares 2005; Datta et al. 2009; Laugier et al. 2005). The growth of the Drosophila eye is 16 interconnected with the organization of both antero-posterior and dorso-ventral axes 17 during development, such as established through the action of Wingless $(\mathrm{Wg})$ and Notch 18 (N) (Dominguez and de Celis 1998; Heberlein et al. 1998; Papayannopoulos et al. 1998). 19 In particular, $\mathrm{N}$ induces proliferation by activating the expression of eyg (Dominguez et al. 20 2004). At the same time, the first wave of retinal determinants, mainly ey and toy, induce 21 and reinforce the expression of other retinal determinants, eya, so and dachsund (dac) 22 (Fig. 2) (reviewed in Casares and Almudi 2016; Davis and Rebay 2017). During differentiation, the activity of Hedgehog ahead of the MF triggers $\mathrm{N}$ 24 dependent activation of the proneural gene atonal (ato) and restriction of its expression in 25 a single cell in each proneural cluster, the R8 cell, which differentiates into the first 26 photoreceptor of the ommatidial cluster (Jarman et al. 1994; Jarman et al. 1995). Similarly, 
1 in zebrafish, retinal neurogenesis has been shown to occur in a wave starting in the optic

2 cup adjacent to the optic stalk and spreading outwards, being preceded by expression of

3 Sonic Hedgehog and the Ato homologue Ath5 (Masai et al. 2000; Neumann and

4 Nuesslein-Volhard 2000). In primates, differentiation also follows sequential waves of gene

5 expression, emanating from the optic disc outward (Cornish et al. 2005; Hendrickson et al.

6 2008) (Fig. 1). Much like Ato in Drosophila, Ath5 in mice seems to be essential to specify

7 the first retinal neurons, the retinal ganglion cells (Brzezinski et al. 2012; Sun et al. 2003).

8 Furthermore, in zebrafish the early differentiating red cones recruit undifferentiated cells to

9 drive further cone cell differentiation, in a process analogous to R8 recruitment of other

10 photoreceptors in Drosophila (Raymond and Barthel 2004). Therefore, the developmental

11 patterning of photoreceptor recruitment from undifferentiated progenitor cells appears to

12 have many similarities between flies and vertebrates (Fig. 1).

In flies, Ato activates the expression of senseless (sens), whereas in the two

14 adjacent remaining cells, Rough inhibits sens to specify the R2 and R5 photoreceptors

15 (Pepple et al. 2008). The rest of the photoreceptors are specified in a sequential manner,

16 involving the activity of the Epidermal Growth Factor Receptor (EGFR) signalling pathway,

17 much of which was first delineated in Drosophila by the analysis of mutants affecting

18 photoreceptor differentiation (Freeman 1996; Freeman 1997; Kumar et al. 1998). During

19 this specification process, photoreceptors are specialized by expression of specific colour-

20 detecting Rhodopsins, a process that shares some similarities again between flies and

21 vertebrates (Fig. 1). In flies, the Otx-family transcription factor Otd regulates the

22 transcriptional repressor Defective Proventriculus (Dve) to regulate rhodopsin gene

23 expression in specific photoreceptor subtypes (Johnston et al. 2011; Yan et al. 2017). In

24 mice, the genes $\mathrm{Nr2e} 3$ and $\mathrm{Nrl}$ also act with Otx-family members, like $\mathrm{Crx}$, the homologue

25 of fly Otd, to activate rod opsin expression and repress cone opsin expression (Cheng et

26 al. 2004; Hennig et al. 2008; Kaewkhaw et al. 2015; Peng et al. 2005). Interestingly, like 
1 Otd, human OTX1 and OTX2 can induce dve expression in Drosophila photoreceptors,

2 suggesting conserved mechanisms of OTX-mediated regulation of photoreceptor specification between flies and humans (Terrell et al. 2012a). Differentiation of yellow and pale ommatidial subtypes in Drosophila is based on the stochastic expression of the PASbHLH transcription factor Spineless, which determines Rh3 expression, being counteracted by Spalt-major (Sal) and Otd to select expression of Rh4 (Johnston et al. 2011; Tahayato et al. 2003; Wernet et al. 2006). Interestingly, in mice, Sall3 (homolog of sal) has been shown to activate opsins and in humans, expression of red versus green opsins also relies on a stochastic mechanism (de Melo et al. 2011; Nathans et al. 1989; Wang et al. 1992). Although different from the one reported in Drosophila, this stochastic

11 mechanism may share aspects of counter-regulation by Sal and OTX factors.

Overall, current research suggests that late photoreceptor specification by regulation of Rhodopsin gene expression shares many conserved mechanisms between human retinal diseases using the Drosophila model.

\section{Insights into human eye conditions from Drosophila}

\section{Drosophila research on Pax6 genes and its impact on understanding eye} developmental diseases

As mentioned above, in both flies and humans, oculogenesis is the product of a conserved gene regulatory network centered on the activity of the master regulator gene Pax6 (Gehring 2014; Quiring et al. 1994). The Drosophila gene ey was first cloned and functionally analyzed, being shown to share a high level of sequence conservation with the Small eye gene in mice and the Aniridia gene in humans, all now collectively established as Pax6 functional homologues. Nearly 300 dominant mutations in the human Pax6 locus have been described, which cause haploinsufficiency. Most of these mutations lead to iris 
1 hypoplasia or total loss of the iris associated with cataracts and corneal changes, a

2 condition designated as aniridia (Glaser et al. 1992; Hanson et al. 1994; Jordan et al.

3 1992; Kaplan and Rozet 2008). Other mutations in Pax6 or other functionally conserved

4 genes in eye development are also the cause of failed embryonic optic fissure closure in

5 MAC spectrum diseases, like anophthalmia, characterized by absence of one or both

6 eyes, microphthalmia, characterised by abnormally small eyes with various malformations,

7 to colobomas, characterized by an open iris, retina, choroid or optic disc (Kaplan and

8 Rozet 2008). Of the eye master regulators, apart from Pax6, mutations in Six5, for

9 example, have been shown promote cataract formation in mice, (Klesert et al.

10 2000; Sarkar et al. 2000) and mutations in EYA1 have been associated with congenital

11 cataracts (Azuma et al. 2000). Despite the differences in development of the optic

12 primordium between Drosophila and vertebrates, Pax6/Ey are necessary to induce eye

13 formation, and ectopic expression of ey or mouse Pax6 is sufficient to induce ectopic eyes

14 (Halder et al. 1995). Additionally, a Drosophila eye-enhancer of ey is capable of driving

15 many features of endogenous Pax6 expression in mice (Xu et al. 1999). These

16 experiments have established the Drosophila model as suitable to study conserved Pax6

17 functions in eye development and disease. It is however, worth noting that based on the

18 human and mice mutant phenotypes, Pax6 in vertebrates seems more critical for lens

19 development.

20 The fly eye, which develops as an evagination of the embryonic ectoderm, much

21 like the vertebrate lens vesicle, may thus bear greater similarities in genetic regulation to

22 this structure than to the whole vertebrate eye (Charlton-Perkins et al. 2011). Of special

23 mention in this respect is the highly conserved regulation of lens Crystallin proteins by

24 Drosophila Pax2 through the same binding sites as vertebrate Pax6 (Blanco et al. 2005;

25 Kozmik et al. 2003). Lens crystallins are a family of ancient proteins, found even in 26 jellyfish, where their expression in lentoid bodies relies on the activity of the ancestral 
1 PaxB transcription factor (Kozmik et al. 2003). In Drosophila, the Pax2 gene appears to

2 have been co-opted into lens development, whereas vertebrate Pax6 has retained or

3 required that function. As such, Drosophila research into Pax2 regulation of Crystallin gene expression may prove essential to uncover mechanisms of vertebrate lens abnormalities in Pax6 mutations.

Regulatory switching of Pax6/ey in eye development is an area of intense research to which Drosophila has contributed significantly. Switching off ey expression is required

8 for photoreceptor fate specification, since mitotic clones that inappropriately maintain high

9 Ey levels fail to activate markers of neuronal differentiation (Atkins et al. 2013). Similarly, in vertebrates, Pax6 is lowly expressed in fully differentiated photoreceptors and high levels

11 of Pax6 have been shown to inhibit differentiation of retinal progenitors (Belecky-Adams et al. 1997; Canto-Soler et al. 2008; Toy et al. 2002).

To achieve this transition, the positive feedback loop that maintains anterior ey expression must be interrupted. In Drosophila, this inhibition results from rewiring the network such that Eya-So directly represses ey transcription in differentiating cells (Atkins et al. 2013). Interestingly, increasing the levels of Eya and So anterior to the MF reduces ey expression (Atkins et al. 2013). Dac appears to be crucial for this switching, as Dac is required for ey repression posterior to the MF and can cooperate with Eya and So to inhibit ey transcription in anterior overexpressing clones (Atkins et al. 2013). One idea is that Dac joins Eya-So to switch the complex into a repressive activity (Davis and Rebay 2017).

21 Although a direct repressive function has not been confirmed in Drosophila, this may be a 22 conserved function of Dac, as mammalian DACH1 can recruit co-repressors and directly 23 repress target gene transcription (Chen et al. 2013; Chu et al. 2014; Li et al. 2003; 24 Sundaram et al. 2008; Wu et al. 2011; Wu et al. 2008; Wu et al. 2009; Wu et al. 2006; Wu et al. 2003; Zhao et al. 2015). On the other hand, mammalian Eya is thought to convert 
1 repressive SIX-DACH complexes to activating EYA-SIX-DACH complexes (Li et al. 2003;

2 Li et al. 2002).

A second example of regulatory switching is the coordination of proliferation with specification in retinal progenitors. Competency to switch from proliferation to specification is initiated when Ey activates transcription of eya and so, which in turn reinforces ey expression and promotes dac transcription (Fig. 1) (Anderson et al. 2006; Atkins et al. 2013; Bonini et al. 1997; Chen et al. 1997; Halder et al. 1998; Niimi et al. 1999; Ostrin

8 2006; Pappu 2005; Pignoni et al. 1997; Salzer and Kumar 2009). Dac then terminates the 9 pro-proliferative role of Hth-Yki complexes by inhibiting $\mathrm{Hth}$ expression and interfering with

10 the ability of Hth-Yki to activate transcription of the pro-growth bantam microRNA (Fig. 1)

11 (Bras-Pereira et al. 2015). Subsequently, Ey cooperates with Eya-So to activate ato 12 transcription, which specifies the first photoreceptor to initiate ommatidial assembly (Fig. 1) 13 (Jemc and Rebay 2007; Zhang et al. 2006; Zhou et al. 2014). This results in a mutual 14 inhibition between the Ey-Hth-Tsh and Ey-Eya-So-Dac signaling networks, which drives precursors from asynchronous proliferation to coordinated differentiation. As in the first switching example, Dac appears to be a key player in the transcriptional repression events

17 that drive developmental transition. How these transitions are orchestrated at the level of chromatin regulation and transcriptional regulation is poorly understood. One idea stemming from Drosophila studies is that core eye determination factors recruit Polycomb group proteins (PcG) to promote switching from proliferative precursors to differentiating

21 retinal cells. Indeed, in a phenotype reminiscent of eya, so, or dac loss, deletion of 22 repressive Polycomb Group genes leads to ectopic Hth and Tsh expression posterior to 23 the MF (Janody et al. 2004). Another intriguing observation is that mutation of skuld or 24 kohtalo, two Trithorax Group genes, leads to inappropriate maintenance of Ey posterior to 25 the MF (Janody et al. 2004). Consistent with this, Eya1 and Six1 recruit the SWI/SNF complex to activate downstream target transcription that drives cochlear neurogenesis 
1 (Ahmed et al. 2012), while Dach1 primarily associates with co-repressors, as discussed

2 above.

As illustrated in the mechanisms delineated in the Drosophila eye model, and by the

\section{Retinal Degeneration Models}

As highlighted earlier in this review, the Drosophila compound eye has little resemblance to the human eye morphologically and yet the gene regulatory networks governing their development are remarkably similar. At a cellular level, the Drosophila and human retinas share many similarities, namely in the structure of photoreceptors and in the genetic and molecular basis of phototransduction, both of which are frequently affected in retinal disease. Since the mid-70s genetic screens have been designed in Drosophila to identify mutations where the morphogenesis of the eye is normal, but photoreceptor cells degenerate from the onset of adult visual function (Harris and Stark 1977; Harris et al. 1976; Hotta and Benzer 1970; Steele and O'Tousa 1990; Yoon et al. 2000). These studies revealed mutants that lead to either a light independent (Bentrop 1998; Lee et al. 1996; Raghu et al. 2000) (Dolph et al. 1993) or light-dependent photoreceptor degeneration (Meyertholen et al. 1987; Stark and Sapp 1987; Steele and O'Tousa 1990). This was of great relevance to understanding the mechanisms of many inherited degenerative diseases that cause blindness in humans, such as Retintis Pigmentosa, a disease that affects 1 in 3000 people, being associated with progressive degeneration from night blindness to full blindness, or Leber Congenital Amaurosis, the most early and severe form of inherited retinal dystrophy, accounting for at least $5 \%$ of inherited retinal diseases 
1 (Kaplan and Rozet 2008). Animal models have shown that retinal degeneration in these

2 cases results from cell death via conserved mechanisms (Chang et al. 1993; Chen et al.

3 1999; Liu et al. 1999). Mutations in humans that cause Retinitis Pigmentosa have been

4 mapped to 35 known genes, and the genetics of their inheritance is complex, from

5 autosomal dominant or recessive to X-linked (Kaplan and Rozet 2008). Mutations in the

6 human rhodopsin genes account for nearly $25 \%$ of the autosomal-dominant retinitis

7 pigmentosa (ADPR) cases (Alemaghtheh et al. 1993; Bhattacharya et al. ; Shokravi and

8 Dryja 1993; Sung et al. 1993). Importantly, many of the mutations uncovered in Drosophila

9 genetic screens affect the synthesis, maturation, intracellular transport, chemical recycling

10 or degradation of the light-sensitive G-protein coupled receptor Rhodopsin.

11 As in vertebrates, the phototransduction cascade in Drosophila is initiated by the

12 photoactivation of a G-protein coupled receptor Rhodopsin covalently linked to a

13 chromophore, the carotenoid 3-hydroxylm, 11-cis retinal (Fig. 2). Light-stimulation induces

14 isomerization of the chromophore thereby inducing a conformational change of Rhodopsin

15 to Metarhodopsin that allows its interaction with a Gqa protein, thereby inducing multiple

16 downstream processes, namely metabolism of diacylglycerol and the ensuing regulation of

17 calcium influx (Fig. 2) (reviewed in Wang and Montell 2007; Xiong and Bellen 2013). The

18 phototransduction is terminated upon Metarhodopsin phosphorylation by GPRK1 and

19 upon Arrestin2 binding, which lead to endocytic internalization (Fig. 2). Early studies in

20 Drosophila revealed that mutations in genes involved in the termination of Metarhodospin

21 activity, including $\operatorname{arr} 2, \operatorname{rdg} B, \operatorname{rdg} C$, norpA and Camta, cause light-dependent retinal

22 degeneration (Fig. 2) (Wang and Montell 2007). In these cases, cell death is light

23 dependent because it depends on the light-induced association of Metarhodopsin with

24 Arrestin, the internalised accumulation of which triggers apoptosis in photoreceptors

25 (Alloway et al. 2000; Kiselev et al. 2000; Kristaponyte et al. 2012). Similar to what happens

26 in Drosophila, the vertebrate Rhodopsin mutant RhK296E, common in autosomal 
1 dominant Retinitis Pigmentosa (ADPR), forms a stable complex with Arrestin and

2 accumulates in the inner segment of photoreceptors (Chen et al. 2006), suggesting this is

3 a conserved mechanism in retinal degeneration between flies and vertebrates. Other

4 Drosophila and vertebrate mutants highlight toxicity due to internalised accumulation of

5 Rhodopsin, such as in genes affecting endolysosomal degradation or the autophagy

6 pathway (Chinchore et al. 2009; Hara et al. 2006; Komatsu et al. 2006; Xu et al. 2004).

7 Furthermore, dominant mutations in Drosophila Rh1 were isolated that cause

8 photoreceptor degeneration only in the heterozygous state (Colley et al. 1995; Kurada and

9 O'Tousa 1995), many being identical to those found in ADRP patients, implying that

10 degeneration is dependent on the existence of both wild type and mutant Rhodopsin and

11 revealing that dominant mutant Rhodopsin interferes with the maturation of wild type

12 Rhodopsin (Colley et al. 1995). Toxicity due to incorrect folding or maturation of Rhodopsin

13 has also been implicated by mutations in the Drosophila chaperones Calnexin and Xport,

14 which lead to Rh1 accumulation in the ER and reduced Rh1 levels in rhabdomeres and

15 thereby cause light-enhanced retinal degeneration (Rosenbaum et al. 2011; Rosenbaum

16 et al. 2006). On the other hand, uncontrolled activity of Rhodopsin can also result in

17 retinal degeneration. Indeed this is the case in the Drosophila Rh1 PP100 mutant, where

18 the mutant opsin persistently binds Arrestin and there is a constitutive activity of the

19 phototransduction cascade (lakhine 2004). In this case, loss of either Arrestin or the Gqa

20 rescues the degenerative phenotype. This mechanism may be relevant to autosomal

21 dominant Congenital Night Blindness, where a mild retinal degeneration is seen as a result

22 of constitutively active forms of rod opsin (Dryja 2000).

23 The transcriptional mechanisms regulating the expression of Rhodopsin genes is 24 yet another important factor commonly affected in retinal diseases. In Drosophila, the 25 transcriptional activation of the Rh3 and Rh5 genes and transcriptional repression of Rh6 26 is orchestrated by the homeodomain protein Otd, and these functions can be partially 
1 complemented by the Human Otd-related genes OTX2 and Crx, both of which are

2 expressed in human cones and rods and regulate many photoreceptor-specific genes

3 (Terrell et al. 2012b). Importantly, several homeodomain mutations in CRX lead to LCA

4 and this mutations have been used to replace Drosophila otd in genetic complementation

5 experiments, revealing differential effects of these mutations on Rhodopsin gene

6 expression and rhabdomeric structure (Terrell et al. 2012b).

Concerning rhabdomeric structure, some Drosophila mutants have been particularly useful in elucidating how this impacts retinal degeneration. In particular mutations affecting

9 the Crumbs complex, formed by the proteins Stardust, Discs-lost/PATJ and Crumbs, were shown to disrupt the correct separation of the rhabdomere from the stalk membrane in

11 photoreceptors (Fig. 3) (Berger et al. 2007; Hong et al. 2003; Pellikka et al. 2002; Richard et al. 2006). Furthermore, mutations affecting the GPI-anchored protein Chaoptin and the

13 transmembrane protein Prominin along with its associated extracellular glycoprotein Eyes 14 Shut, prevent the separation of adjacent rhabdomeric membranes and disrupt the interrhabdomeral space (Fig. 3) (Cook and Zelhof 2008; Gurudev et al. 2014; Husain et al. 2006; Nie et al. 2012; Zelhof et al. 2006). These mutations result in light-dependent

17 photoreceptor degeneration possibly as a direct consequent of loss of localisation of 18 Rhodopsin and other proteins to the rhabdomeric membrane. Indeed, these effects are 19 similar to architectural defects seen in the rhabdomeres of null or strong mutants of 20 Drosophila Rh1 (Kurada and O'Tousa 1995; Leonard et al. 1992). Importantly, Crumbs 21 has been shown to interact and stabilise Myosin V and thereby promote trafficking of Rh1 22 to the rhabdomeres (Pocha et al. 2011). This mechanism may bear relevance to cases of 23 autosomal recessive Retinitis Pigmentosa and Leber Congenital Amaurosis and 24 autosomal dominant pigmented paravenous chorioretinal atrophy associated with mutations in the human CRB1 gene (Cremers et al. 2002; den Hollander et al. 2010; den Hollander et al. 2001; Den Hollander et al. 1999; Jacobson et al. 2003; Lotery et al. 2001; 
1 McKay et al. 2005), or in autosomal recessive retinal degeneration caused by mutation in

2 human PROMINI-1 (Maw et al. 2000), or RP25, orthologue of Drosophila Eyes Shut (Abd

3 El-Aziz et al. 2008; Alfano et al. 2016; Yu et al. 2016).

Critically, Drosophila research has contributed to highlight targets for therapeutical

5 approaches to many of the degenerations reported above. The chemical transformations

6 of dietary carotenoids into 3-hydroxylm, 11-cis retinal, were shown to be important

7 modulators of light-induced retinal degeneration (Voolstra et al. 2010; Wang et al. 2010;

8 Wang et al. 2012). Limiting de-novo chromophore synthesis, via B-carotene/Vitamin-A

9 dietary depletion, can greatly reduce Rhodopsin levels, thus significantly rescuing light-

10 induced retinal degeneration in mutants affecting the stability of the metharodopsin-

11 arrestin2 complex (Alloway et al. 2000; Berger et al. 2007; Kiselev et al. 2000; Richard et

12 al. 2006), and similarly in crumbs, stardust and PATJ mutant eyes (Johnson et al. 2002).

On the other hand, in cases of accumulation of immature Rhodopsin, a Drosophila

14 study has shown that boosting ER-associated degradation (ERAD), by overexpression of

15 the ERAD factors Hrd1 and EDEM2, reduces mutant Rh1 levels in dominant RhG69D

16 mutants, thereby delaying retinal degeneration (Kang and Ryoo 2009). Intriguingly, genetic

17 inactivation of the ERAD effector chaperone VCP/ter94 in Drosophila or its chemical

18 inhibition with Eeyarestatin I, led to strong suppression of retinal degeneration caused by

19 accumulation of the immature RhP23H mutant (Griciuc et al. 2010). These apparently

20 conflicting observations hint at different mechanisms of dominance of Rh1 mutations and

21 argue that manipulation of ERAD for therapeutic purposes should consider these

22 differences carefully. Similar to the effects observed for manipulation of ERAD,

23 potentiating autophagy or lysosomal degradation pathways, can effectively reduce

24 Rhodopsin accumulation and ameliorate retinal degeneration (Lee et al. 2013; Wang et al.

25 2009). 
A possible mechanism underlying the degeneration upon subcellular Rhodopsin

2 accumulation is an overload of cytoplasmic Ca2+ influx (Orrenius et al. 2003). Cytoplasmic

3 Ca2+ influx induces the dephosphorylation of metharhodopsin by CAMKII, and therefore,

4 low levels of $\mathrm{Ca} 2+$ can lead to accumulation of internalized Metharhodopsin-Arrestin complexes and cause photoreceptor degeneration (Chinchore et al. 2009; Kiselev et al. 2000; Orem and Dolph 2002). This is also seen in loss of function mutations in TRP

7 calcium channels, but simultaneous counterbalancing mutations in the $\mathrm{Ca}+/ \mathrm{Na} 2+$ exchanger CalX or the Diacylglycerol Kinase, RDGA, can greatly suppress light-induced retinal degeneration, indicating that balanced $\mathrm{Ca} 2+$ levels are critical for photoreceptor survival (Fig. 3) (Raghu et al. 2000; Wang et al. 2005). Cytoplasmic Ca2+ influx during the

11 photo-response is modulated by the levels of PIP2 and their effect on calcium channels.

12 Interestingly, an altered PIP2 regeneration cycle in Drosophila photoreceptors, such as 13 through mutations affecting the Diacylglycerol Kinase, RDGA, or the Phosphatidate 14 phosphatase, Lazaro, or overexpression of phospholipase D, can all modify light-induced neurodegeneration phenotypes (Garcia-Murillas et al. 2006; Inoue et al. 1989; Kwon and Montell 2006; LaLonde et al. 2006; Masai et al. 1993).

It has been suggested that dominant negative mutations in Rhodopsin associated with Retinitis Pigmentosa could be especially amenable to gene therapy, as providing extra dosage of Rhodopsin was shown to significantly ameliorate the cell death observed in the Rh P23H mouse model (Lewin et al. 2014; Mao et al. 2011). However, too much

21 Rhodopsin overexpression was also shown to cause retinal degeneration in this case, 22 indicating that Rhodopsin augmentation needs to be tightly controlled for therapeutic 23 purposes. In Drosophila, it was also noticed that expression of phosphorylation deficient 24 Rhodopsin could offer protective effects in norpA mutant photoreceptors, indicating that modulation of Rhodopsin phosphorylation is critical to prevent its high levels of toxic internalization in light-dependent retinal degeneration (Kristaponyte et al. 2012). 
With the advent of CRISPR/Cas9 technology, it is now possible to realize many of

2 these gene therapy changes, albeit cautiously considering possible off-target effects.

3 Recently, AAV-mediated CRISPR/Cas9 targeting of Nrl, a rod-specific transcription factor,

\section{Future perspectives} was shown to improve rod survival in a mouse Rh P374S mutant (Yu et al. 2017). Furthermore, CRISPR/Cas9 targeting of the Rh P23H allele has been achieved efficiently in a null background both in the mouse and pig retina, offering a great promise for gene therapy (Burnight et al. 2017; Latella et al. 2016). Alternatively, using an artificial transcription factor, it was recently possible to repress a faulty Rhodopsin gene in pigs, while maintaining normal expression of the wild type Rhodopsin (Botta et al. 2016).

The genetic basis of most eye conditions, for example anophthalmia and microphthalmia, has only been characterised in less than $30 \%$ of cases (Chassaing et al. 2014; Williamson and FitzPatrick 2014). This low rate of diagnosis is caused in part by the polygenic nature of eye development and by the fact that many cases are caused by rare variants. This is exacerbated by a poor understanding of the function of most human genes. Further functional analysis of known disease causing genes and screens for new candidates in Drosophila has great potential to improve diagnosis and better understand the underlying mechanisms (Wangler et al. 2017). This was exemplified recently by an elegant screen in Drosophila for lethal mutations in genes involved in sensory functions and crossreferencing with human exome data (Yamamoto et al. 2014). This study allowed the diagnosis of conditions in several individuals including in a new role for Crx in bull's eye maculopathy where the phenotypic effect on photoreceptors was similar in flies and humans (Yamamoto et al. 2014). This was facilitated by the availability of sophisticated approaches for screening and powerful tools for genetic and phenotypic analysis in this model. Therefore it is clear that the Drosophila eye will continue to be an excellent and 
1 economic model to study eye conditions as well as other diseases (Chow and Reiter 2017;

2 Kumar 2018; Senturk and Bellen 2017; Yamamoto et al. 2014). This can be enhanced by

3 further collaborations between clinicians and researchers working on Drosophila (Wangler

4 et al. 2015) as part of national and international initiatives such as the Undiagnosed

5 Diseases Network (Gahl et al. 2016) and tools such as GeneMatcher (Sobreira et al.

6 2015a; Sobreira et al. 2015b).

7

\section{Acknowledgements}

9 PG and APM are funded by BBSRC grant BB/M020967/1. IA has received funding from

10 Apoyo a Unidades de Excelencia María de Maeztu from the Ministry of Economy, Industry

11 and Competitiveness of Spain.

12

\section{Conflict of interest statement}

14 On behalf of all authors, the corresponding author states that there is no conflict of 15 interest.

16 


\section{References}

Abd El-Aziz MM, Barragan I, O'Driscoll CA, Goodstadt L, Prigmore E, Borrego S, Mena M, Pieras JI, El-Ashry MF, Safieh LA, Shah A, Cheetham ME, Carter NP, Chakarova C, Ponting CP, Bhattacharya SS, Antinolo G (2008) EYS, encoding an ortholog of Drosophila spacemaker, is mutated in autosomal recessive retinitis pigmentosa. Nature Genetics 40: 1285-1287. doi: 10.1038/ng.241

Adams MD, Celniker SE, Holt RA, Evans CA, Gocayne JD, Amanatides PG, Scherer SE, Li PW, Hoskins RA, Galle RF, George RA, Lewis SE, Richards S, Ashburner M, Henderson SN, Sutton GG, Wortman JR, Yandell MD, Zhang Q, Chen LX, Brandon RC, Rogers YH, Blazej RG, Champe M, Pfeiffer BD, Wan KH, Doyle C, Baxter EG, Helt G, Nelson CR, Gabor GL, Abril JF, Agbayani A, An HJ, Andrews-Pfannkoch C, Baldwin D, Ballew RM, Basu A, Baxendale J, Bayraktaroglu L, Beasley EM, Beeson KY, Benos PV, Berman BP, Bhandari D, Bolshakov S, Borkova D, Botchan MR, Bouck J, Brokstein P, Brottier P, Burtis KC, Busam DA, Butler H, Cadieu E, Center A, Chandra I, Cherry JM, Cawley S, Dahlke C, Davenport LB, Davies P, de Pablos B, Delcher A, Deng Z, Mays AD, Dew I, Dietz SM, Dodson K, Doup LE, Downes M, Dugan-Rocha S, Dunkov BC, Dunn P, Durbin KJ, Evangelista CC, Ferraz C, Ferriera S, Fleischmann W, Fosler C, Gabrielian AE, Garg NS, Gelbart WM, Glasser K, Glodek A, Gong F, Gorrell JH, Gu Z, Guan P, Harris M, Harris NL, Harvey D, Heiman TJ, Hernandez JR, Houck J, Hostin D, Houston KA, Howland TJ, Wei $\mathrm{MH}$, Ibegwam C, et al. (2000) The genome sequence of Drosophila melanogaster. Science 287: $2185-95$

Ahmed M, Wong EYM, Sun J, Xu J, Wang F, Xu PX (2012) Eya1-Six1 Interaction Is Sufficient to Induce Hair Cell Fate in the Cochlea by Activating Atoh1 Expression in Cooperation with Sox2. Developmental Cell 22: 377-390. doi: 10.1016/j.devcel.2011.12.006

Aldahmesh MA, Khan AO, Hijazi H, Alkuraya FS (2013) Homozygous truncation of SIX6 causes complex microphthalmia in humans. Clin Genet 84: 198-9. doi: 10.1111/cge.12046

Aldaz S, Morata G, Azpiazu N (2003) The Pax-homeobox gene eyegone is involved in the subdivision of the thorax of Drosophila. Development (Cambridge, England) 130: 44734482. doi: $10.1242 /$ dev.00643 
Alemaghtheh M, Gregory C, Inglehearn C, Hardcastle A, Bhattacharya S (1993) Rhodopsin Mutations in Autosomal Dominant Retinitis Pigmentma. Human Mutation 255: 249-255.

Alfano G, Kruczek PM, Shah AZ, Kramarz B, Jeffery G, Zelhof AC, Bhattacharya SS (2016) EYS is a protein associated with the ciliary axoneme in rods and cones. PLoS ONE 11: 1-20. doi: 10.1371/journal.pone. 0166397

Alloway PG, Howard L, Dolph PJ (2000) The formation of stable rhodopsin-arrestin complexes induces apoptosis and photoreceptor cell degeneration. Neuron 28: 129-138. doi: 10.1016/S0896-6273(00)00091-X

Anderson J, Salzer CL, Kumar JP (2006) Regulation of the retinal determination gene dachshund in the embryonic head and developing eye of Drosophila. Developmental Biology 297: 536549. doi: 10.1016/j.ydbio.2006.05.004

Atkins M, Jiang Y, Sansores-Garcia L, Jusiak B, Halder G, Mardon G (2013) Dynamic Rewiring of the Drosophila Retinal Determination Network Switches Its Function from Selector to Differentiation. PLoS Genetics 9. doi: 10.1371/journal.pgen.1003731

Azuma N, Hirakiyama A, Inoue T, Asaka A, Yamada M (2000) Mutations of a human homologue of the Drosophila eyes absent gene (EYA1) detected in patients with congenital cataracts and ocular anterior segment anomalies. Hum Mol Genet 9: 363-6.

Belecky-Adams T, Tomarev S, Li HS, Ploder L, Mclnnes RR, Sundin O, Adler R (1997) Pax-6, Prox 1, and Chx10 homeobox gene expression correlates with phenotypic fate of retinal precursor cells. Invest Ophthalmol Vis Sci 38: 1293-303.

Bentrop J (1998) Rhodopsin mutations as the cause of retinal degeneration - Classification of degeneration phenotypes in the model system Drosophila melanogaster. Acta Anatomica 162: 85-94. doi: aan62085 [pii]

Benzer S (1967) BEHAVIORAL MUTANTS OF Drosophila ISOLATED BY COUNTERCURRENT DISTRIBUTION. Proc Natl Acad Sci U S A 58: 1112-9.

Berger S, Bulgakova NA, Grawe F, Johnson K, Knust E (2007) Unraveling the genetic complexity of drosophila stardust during photoreceptor morphogenesis and prevention of light-induced degeneration. Genetics 176: 2189-2200. doi: 10.1534/genetics.107.071449 
Bessa J, Carmona L, Casares F (2009) Zinc-finger paralogues tsh and tio are functionally equivalent during imaginal development in Drosophila and maintain their expression levels through auto- and cross-negative feedback loops. Dev Dyn 238: 19-28. doi: $10.1002 / d v d y .21808$

Bessa J, Casares F (2005) Restricted teashirt expression confers eye-specific responsiveness to Dpp and Wg signals during eye specification in Drosophila. Development 132: 5011-20. doi: $10.1242 /$ dev. 02082

Bhattacharya S, Lester D, Keen J, Bashir R, Lauffart B, Inglehearn C, Jay M, Bird A Retinitis pigmentosa and mutations in rhodopsin. The Lancet 337: 185. doi: 10.1016/01406736(91)90858-M

Blanco J, Girard F, Kamachi Y, Kondoh H, Gehring WJ (2005) Functional analysis of the chicken delta1-crystallin enhancer activity in Drosophila reveals remarkable evolutionary conservation between chicken and fly. Development 132: 1895-905. doi: 10.1242/dev. 01738

Bonini NM, Bui QT, Gray-Board GL, Warrick JM (1997) The Drosophila eyes absent gene directs ectopic eye formation in a pathway conserved between flies and vertebrates. Development 124: $4819-4826$.

Bonini NM, Leiserson WM, Benzer S (1993) The eyes absent gene: Genetic control of cell survival and differentiation in the developing Drosophila eye. Cell 72: 379-395. doi: 10.1016/00928674(93)90115-7

Borst A (2009) Drosophila's view on insect vision. Curr Biol 19: R36-47. doi: 10.1016/j.cub.2008.11.001

Botta S, Marrocco E, de Prisco N, Curion F, Renda M, Sofia M, Lupo M, Carissimo A, Bacci ML, Gesualdo C, Rossi S, Simonelli F, Surace EM (2016) Rhodopsin targeted transcriptional silencing by DNA-binding. eLife 5: 1-14. doi: 10.7554/eLife.12242

Bras-Pereira C, Casares F, Janody F (2015) The retinal determination gene dachshund restricts cell proliferation by limiting the activity of the Homothorax-Yorkie complex. Development 142: 1470-1479. doi: $10.1242 / \operatorname{dev} .113340$ 
Brzezinski JAt, Prasov L, Glaser T (2012) Math5 defines the ganglion cell competence state in a subpopulation of retinal progenitor cells exiting the cell cycle. Dev Biol 365: 395-413. doi: 10.1016/j.ydbio.2012.03.006

Burke C, Trinh K, Nadar V, Sanyal S (2017) AxGxE: Using Flies to Interrogate the Complex Etiology of Neurodegenerative Disease. Curr Top Dev Biol 121: 225-251. doi: 10.1016/bs.ctdb.2016.07.007

Burnight ER, Gupta M, Wiley LA, Anfinson KR, Tran A, Triboulet R, Hoffmann JM, Klaahsen DL, Andorf JL, Jiao C, Sohn EH, Adur MK, Ross JW, Mullins RF, Daley GQ, Schlaeger TM, Stone EM, Tucker BA (2017) Using CRISPR-Cas9 to Generate Gene-Corrected Autologous iPSCs for the Treatment of Inherited Retinal Degeneration. Molecular Therapy 25: 1999-2013. doi: 10.1016/j.ymthe.2017.05.015

Cagan R (2009) Principles of Drosophila eye differentiation. Curr Top Dev Biol 89: 115-35. doi: $10.1016 / \mathrm{s} 0070-2153(09) 89005-4$

Canto-Soler MV, Huang H, Romero MS, Adler R (2008) Transcription factors CTCF and Pax6 are segregated to different cell types during retinal cell differentiation. Dev Dyn 237: 758-67. doi: $10.1002 /$ dvdy.21420

Casares F, Almudi I (2016) Fast and Furious 800. The Retinal Determination Gene Network in Drosophila. In: Castelli-Gair Hombría J, Bovolenta P (eds) Organogenetic Gene Networks: Genetic Control of Organ Formation. Springer International Publishing, Cham, pp 95-124

Chang GQ, Hao Y, Wong F (1993) Apoptosis: final common pathway of photoreceptor death in rd, rds, and rhodopsin mutant mice. Neuron 11: 595-605.

Chao J-L (2004) Localized Notch signal acts through eyg and upd to promote global growth in Drosophila eye. Development 131: 3839-3847. doi: 10.1242/dev.01258

Charlton-Perkins M, Brown NL, Cook TA (2011) The lens in focus: a comparison of lens development in Drosophila and vertebrates. Mol Genet Genomics 286: 189-213. doi: $10.1007 / \mathrm{s} 00438-011-0643-y$

Chassaing N, Causse A, Vigouroux A, Delahaye A, Alessandri JL, Boespflug-Tanguy O, BouteBenejean O, Dollfus H, Duban-Bedu B, Gilbert-Dussardier B, Giuliano F, Gonzales M, Holder-Espinasse M, Isidor B, Jacquemont ML, Lacombe D, Martin-Coignard D, Mathieu- 
Dramard M, Odent S, Picone O, Pinson L, Quelin C, Sigaudy S, Toutain A, ThauvinRobinet C, Kaplan J, Calvas P (2014) Molecular findings and clinical data in a cohort of 150 patients with anophthalmia/microphthalmia. Clin Genet 86: 326-34. doi: 10.1111/cge.12275

Chen CK, Burns ME, Spencer M, Niemi GA, Chen J, Hurley JB, Baylor DA, Simon MI (1999) Abnormal photoresponses and light-induced apoptosis in rods lacking rhodopsin kinase. Proc Natl Acad Sci U S A 96: 3718-22.

Chen J, Shi G, Concepcion FA, Xie G, Oprian D, Chen J (2006) Stable rhodopsin/arrestin complex leads to retinal degeneration in a transgenic mouse model of autosomal dominant retinitis pigmentosa. J Neurosci 26: 11929-37. doi: 10.1523/jneurosci.3212-06.2006

Chen K, Wu K, Cai S, Zhang W, Zhou J, Wang J, Ertel A, Li Z, Rui H, Quong A, Lisanti MP, Tozeren A, Tanes C, Addya S, Gormley M, Wang C, McMahon SB, Pestell RG (2013) Dachshund binds p53 to block the growth of lung adenocarcinoma cells. Cancer Research 73: 3262-3274. doi: 10.1158/0008-5472.CAN-12-3191

Chen R, Amoui M, Zhang Z, Mardon G (1997) Dachshund and eyes absent proteins form a complex and function synergistically to induce ectopic eye development in Drosophila. Cell 91: 893-903. doi: 10.1016/S0092-8674(00)80481-X

Cheng H, Khanna H, Oh EC, Hicks D, Mitton KP, Swaroop A (2004) Photoreceptor-specific nuclear receptor NR2E3 functions as a transcriptional activator in rod photoreceptors. Hum Mol Genet 13: 1563-75. doi: 10.1093/hmg/ddh173

Cheyette BNR, Green PJ, Martin K, Garren H, Hartenstein V, Zipursky SL (1994) The drosophila sine oculis locus encodes a homeodomain-containing protein required for the development of the entire visual system. Neuron 12: 977-996. doi: 10.1016/0896-6273(94)90308-5

Chinchore Y, Mitra A, Dolph PJ (2009) Accumulation of rhodopsin in late endosomes triggers photoreceptor cell degeneration. PLoS Genetics 5. doi: 10.1371/journal.pgen.1000377

Chow CY, Reiter LT (2017) Etiology of Human Genetic Disease on the Fly. Trends Genet 33: 391398. doi: 10.1016/j.tig.2017.03.007

Chu Q, Han N, Yuan X, Nie X, Wu H, Chen Y, Guo M, Yu S, Wu K (2014) DACH1 inhibits cyclin D1 expression, cellular proliferation and tumor growth of renal cancer cells. Journal of Hematology \& Oncology 7: 73. doi: 10.1186/s13045-014-0073-5 
Colley NJ, Cassillt JA, Baker EK, Zukert CS, Rosenfeld MG (1995) Defective intracellular transport is the molecular basis of rhodopsin-dependent dominant retinal degeneration. Genetics 92: 3070-3074.

Cook B, Zelhof AC (2008) Photoreceptors in evolution and disease. Nature Genetics 40: 12751276. doi: $10.1038 / \mathrm{ng} 1108-1275$

Cornish EE, Madigan MC, Natoli R, Hales A, Hendrickson AE, Provis JM (2005) Gradients of cone differentiation and FGF expression during development of the foveal depression in macaque retina. Vis Neurosci 22: 447-59. doi: 10.1017/s0952523805224069

Cremers FPM, van den Hurk JAJM, den Hollander Al (2002) Molecular genetics of Leber congenital amaurosis. Human molecular genetics 11: 1169-1176. doi: 10.1093/hmg/11.10.1169

Crowley MA, Conlin LK, Zackai EH, Deardorff MA, Thiel BD, Spinner NB (2010) Further evidence for the possible role of MEIS2 in the development of cleft palate and cardiac septum. Am J Med Genet A 152A: 1326-7. doi: 10.1002/ajmg.a.33375

Czerny T, Halder G, Kloter U, Souabni A, Gehring WJ, Busslinger M (1999) Twin of eyeless, a second Pax-6 gene of Drosophila, acts upstream of eyeless in the control of eye development. Molecular Cell 3: 297-307. doi: 10.1016/S1097-2765(00)80457-8

Datta RR, Lurye JM, Kumar JP (2009) Restriction of ectopic eye formation by Drosophila teashirt and tiptop to the developing antenna. Dev Dyn 238: 2202-10. doi: 10.1002/dvdy.21927

Davis TL, Rebay I (2017) Master regulators in development: Views from the Drosophila retinal determination and mammalian pluripotency gene networks. Developmental Biology 421: 93-107. doi: 10.1016/j.ydbio.2016.12.005

de Melo J, Peng GH, Chen S, Blackshaw S (2011) The Spalt family transcription factor Sall3 regulates the development of cone photoreceptors and retinal horizontal interneurons. Development 138: 2325-36. doi: 10.1242/dev.061846

den Hollander Al, Biyanwila J, Kovach P, Bardakjian T, Traboulsi El, Ragge NK, Schneider A, Malicki J (2010) Genetic defects of GDF6 in the zebrafish out of sight mutant and in human eye developmental anomalies. BMC Genet 11: 102. doi: 10.1186/1471-2156-11-102 
den Hollander AI, Heckenlively JR, van den Born LI, de Kok YJ, van der Velde-Visser SD, Kellner U, Jurklies B, van Schooneveld MJ, Blankenagel A, Rohrschneider K, Wissinger B, Cruysberg JR, Deutman AF, Brunner HG, Apfelstedt-Sylla E, Hoyng CB, Cremers FP (2001) Leber congenital amaurosis and retinitis pigmentosa with Coats-like exudative vasculopathy are associated with mutations in the crumbs homologue 1 (CRB1) gene. American journal of human genetics 69: 198-203. doi: 10.1086/321263

Den Hollander AI, Ten Brink JB, De Kok YJM, Van Soest S, Van Den Born LI, Van Driel MA, Van De Pol DJR, Payne AM, Bhattacharya SS, Kellner U, Hoyng CB, Westerveld A, Brunner HG, Bleeker-Wagemakers EM, Deutman AF, Heckenlively JR, Cremers FPM, Bergen AAB (1999) Mutations in a human homologue of Drosophila crumbs cause retinitis pigmentosa (RP12). Nature Genetics 23: 217-221. doi: 10.1038/13848

Desplan C (1997) Eye development: Governed by a dictator or a junta? Cell 91: 861-864. doi: $10.1016 / S 0092-8674(00) 80475-4$

Dominguez M, de Celis JF (1998) A dorsal/ventral boundary established by Notch controls growth and polarity in the Drosophila eye. Nature 396: 276-8.

Dominguez M, Ferres-Marco D, Gutierrez-Aviño FJ, Speicher SA, Beneyto M (2004) Growth and specification of the eye are controlled independently by Eyegone and Eyeless in Drosophila melanogaster. Nature Genetics 36: 31-39. doi: 10.1038/ng1281

Dryja TP (2000) Molecular genetics of Oguchi disease, fundus albipunctatus, and other forms of stationary night blindness: LVII Edward Jackson Memorial Lecture. American Journal of Ophthalmology 130: 547-563. doi: 10.1016/S0002-9394(00)00737-6

Dryja TP, Hahn LB, Cowley GS, McGee TL, Berson EL (1991) Mutation spectrum of the rhodopsin gene among patients with autosomal dominant retinitis pigmentosa. Proc Natl Acad Sci U S A 88: $9370-4$.

Dryja TP, McGee TL, Reichel E, Hahn LB, Cowley GS, Yandell DW, Sandberg MA, Berson EL (1990) A point mutation of the rhodopsin gene in one form of retinitis pigmentosa. Nature 343: 364-6. doi: $10.1038 / 343364 a 0$

Favor J, Sandulache R, Neuhäuser-Klaus a, Pretsch W, Chatterjee B, Senft E, Wurst W, Blanquet V, Grimes P, Spörle R, Schughart K (1996) The mouse Pax2(1Neu) mutation is identical to 
a human PAX2 mutation in a family with renal-coloboma syndrome and results in developmental defects of the brain, ear, eye, and kidney. Proceedings of the National Academy of Sciences of the United States of America 93: 13870-5. doi: 10.1073/pnas.93.24.13870

Freeman M (1996) Reiterative use of the EGF receptor triggers differentiation of all cell types in the Drosophila eye. Cell 87: 651-660. doi: 10.1016/S0092-8674(00)81385-9

Freeman M (1997) Cell determination strategies in the Drosophila eye. Development 124: 261-70.

Freund CL, Gregory-Evans CY, Furukawa T, Papaioannou M, Looser J, Ploder L, Bellingham J, Ng D, Herbrick JA, Duncan A, Scherer SW, Tsui LC, Loutradis-Anagnostou A, Jacobson SG, Cepko CL, Bhattacharya SS, McInnes RR (1997) Cone-rod dystrophy due to mutations in a novel photoreceptor-specific homeobox gene (CRX) essential for maintenance of the photoreceptor. Cell 91: 543-53.

Freund CL, Wang QL, Chen S, Muskat BL, Wiles CD, Sheffield VC, Jacobson SG, Mclnnes RR, Zack DJ, Stone EM (1998) De novo mutations in the CRX homeobox gene associated with Leber congenital amaurosis. Nat Genet 18: 311-2. doi: 10.1038/ng0498-311

Fu W, Duan H, Frei E, Noll M (1998) shaven and sparkling are mutations in separate enhancers of the Drosophila Pax2 homolog. Development 125: 2943-50.

Gahl WA, Mulvihill JJ, Toro C, Markello TC, Wise AL, Ramoni RB, Adams DR, Tifft CJ (2016) The NIH Undiagnosed Diseases Program and Network: Applications to modern medicine. Mol Genet Metab 117: 393-400. doi: 10.1016/j.ymgme.2016.01.007

Garcia-Murillas I, Pettitt T, Macdonald E, Okkenhaug H, Georgiev P, Trivedi D, Hassan B, Wakelam M, Raghu P (2006) lazaro encodes a lipid phosphate phosphohydrolase that regulates phosphatidylinositol turnover during Drosophila phototransduction. Neuron 49: 533-546. doi: 10.1016/j.neuron.2006.02.001

Gehring WJ (1996) The master control gene for morphogenesis and evolution of the eye. Genes to cells : devoted to molecular \& cellular mechanisms 1: 11-5. doi: 10.1046/j.13652443.1996.11011.x

Gehring WJ (2005) New perspectives on eye development and the evolution of eyes and photoreceptors. J Hered 96: 171-84. doi: esi027 [pii] 
10.1093/jhered/esi027

Gehring WJ (2014) The evolution of vision. Wiley Interdisciplinary Reviews: Developmental Biology 3: 1-40. doi: 10.1002/wdev.96

Ghiasvand NM, Rudolph DD, Mashayekhi M, Brzezinski JAt, Goldman D, Glaser T (2011) Deletion of a remote enhancer near ATOH7 disrupts retinal neurogenesis, causing NCRNA disease. Nat Neurosci 14: 578-86. doi: 10.1038/nn.2798

Glaser T, Walton DS, Maas RL (1992) Genomic structure, evolutionary conservation and aniridia mutations in the human PAX6 gene. Nature Genetics 2: 232-239. doi: 10.1038/ng1192-232

Green P, Hartenstein AY, Hartenstein V (1993) The embryonic development of the Drosophila visual system. Cell Tissue Res 273: 583-98.

Griciuc A, Aron L, Roux MJ, Klein R, Giangrande A, Ueffing M (2010) Inactivation of VCP/ter94 suppresses retinal pathology caused by misfolded Rhodopsin in Drosophila. PLoS Genetics 6. doi: 10.1371/journal.pgen.1001075

Gurudev N, Yuan M, Knust E (2014) chaoptin, prominin, eyes shut and crumbs form a genetic network controlling the apical compartment of Drosophila photoreceptor cells. Biology Open 3: 332-341. doi: 10.1242/bio.20147310

Halder G, Callaerts P, Flister S, Walldorf U, Kloter U, Gehring WJ (1998) Eyeless initiates the expression of both sine oculis and eyes absent during Drosophila compound eye development. Development (Cambridge, England) 125: 2181-2191.

Halder G, Callaerts P, Gehring W (1995) Induction of ectopic eyes by targeted expression of the eyeless gene in Drosophila. Science 267: 1788-1792. doi: 10.1126/science.7892602

Hanson IM, Fletcher JM, Jordan T, Brown A, Taylor D, Adams RJ, Punnett HH, van Heyningen V (1994) Mutations at the PAX6 locus are found in heterogeneous anterior segment malformations including Peters' anomaly. Nature Genetics 6: 168-173. doi: $10.1038 / n g 0294-168$

Hara T, Nakamura K, Matsui M, Yamamoto A, Nakahara Y, Suzuki-Migishima R, Yokoyama M, Mishima K, Saito I, Okano H, Mizushima N (2006) Suppression of basal autophagy in neural cells causes neurodegenerative disease in mice. Nature 441: 885-889. doi: 10.1038/nature04724 
Harris Wa, Stark WS (1977) Hereditary retinal degeneration in Drosophila melanogaster. A mutant defect associated with the phototransduction process. The Journal of general physiology 69: 261-91. doi: 10.1085/jgp.69.3.261

Harris WA, Stark WS, Walker JA (1976) Genetic Dissection of Photoreceptor System in Compound Eye of Drosophila-Melanogaster. Journal of Physiology-London 256: 415-\&.

Heberlein U, Borod ER, Chanut FA (1998) Dorsoventral patterning in the Drosophila retina by wingless. Development 125: 567-77.

Hendrickson A, Bumsted-O'Brien K, Natoli R, Ramamurthy V, Possin D, Provis J (2008) Rod photoreceptor differentiation in fetal and infant human retina. Exp Eye Res 87: 415-26. doi: 10.1016/j.exer.2008.07.016

Hennig AK, Peng GH, Chen S (2008) Regulation of photoreceptor gene expression by Crxassociated transcription factor network. Brain Res 1192: 114-33. doi: 10.1016/j.brainres.2007.06.036

Hilbrant M, Almudi I, Leite DJ, Kuncheria L, Posnien N, Nunes MDS, McGregor AP (2014) Data from: Sexual dimorphism and natural variation within and among species in the Drosophila retinal mosaic. BMC Evolutionary Biology, Http

Hong Y, Ackerman L, Jan LY, Jan Y-N (2003) Distinct roles of Bazooka and Stardust in the specification of Drosophila photoreceptor membrane architecture. Proceedings of the National Academy of Sciences of the United States of America 100: 12712-12717. doi: 10.1073/pnas.2135347100

Hoskins BE, Cramer CH, Silvius D, Zou D, Raymond RM, Orten DJ, Kimberling WJ, Smith RJ, Weil D, Petit C, Otto EA, Xu PX, Hildebrandt F (2007) Transcription factor SIX5 is mutated in patients with branchio-oto-renal syndrome. Am J Hum Genet 80: 800-4. doi: $10.1086 / 513322$

Hotta Y, Benzer S (1970) Genetic dissection of the Drosophila nervous system by means of mosaics. Proc Natl Acad Sci U S A 67: 1156-63.

Husain N, Pellikka M, Hong H, Klimentova T, Choe KM, Clandinin TR, Tepass U (2006) The Agrin/Perlecan-Related Protein Eyes Shut Is Essential for Epithelial Lumen Formation in the Drosophila Retina. Developmental Cell 11: 483-493. doi: 10.1016/j.devcel.2006.08.012 
lakhine R (2004) Novel Dominant Rhodopsin Mutation Triggers Two Mechanisms of Retinal Degeneration and Photoreceptor Desensitization. Journal of Neuroscience 24: 2516-2526. doi: 10.1523/JNEUROSCI.5426-03.2004

Inoue H, Yoshioka T, Hotta $\mathrm{Y}$ (1989) Diacylglycerol kinase defect in a Drosophila retinal degeneration mutant rdgA. Journal of Biological Chemistry 264: 5996-6000.

Jacobson SG, Cideciyan AV, Aleman TS, Pianta MJ, Sumaroka A, Schwartz SB, Smilko EE, Milam AH, Sheffield VC, Stone EM (2003) Crumbs homolog 1 (CRB1) mutations result in a thick human retina with abnormal lamination. Human Molecular Genetics 12: 1073-1078. doi: $10.1093 / \mathrm{hmg} / \mathrm{ddg} 117$

Jang C-C, Chao J-L, Jones N, Yao L-C, Bessarab DA, Kuo YM, Jun S, Desplan C, Beckendorf SK, Sun YH (2003) Two Pax genes, eye gone and eyeless, act cooperatively in promoting Drosophila eye development. Development (Cambridge, England) 130: 2939-51. doi: 10.1242/dev.00522

Janody F, Lee JD, Jahren N, Hazelett DJ, Benlali A, Miura GI, Draskovic I, Treisman JE (2004) A Mosaic Genetic Screen Reveals Distinct Roles for trithorax and Polycomb Group Genes in Drosophila Eye Development. Genetics 166: 187-200. doi: 10.1534/genetics.166.1.187

Jarman AP, Grell EH, Ackerman L, Jan LY, Jan YN (1994) Atonal is the proneural gene for Drosophila photoreceptors. Nature 369: 398-400.

Jarman AP, Sun Y, Jan LY, Jan YN (1995) Role of the proneural gene, atonal, in formation of Drosophila chordotonal organs and photoreceptors. Development 121: 2019-30.

Jemc J, Rebay I (2007) Identification of transcriptional targets of the dual-function transcription factor/phosphatase eyes absent. Developmental Biology 310: 416-429. doi: 10.1016/j.ydbio.2007.07.024

Johnson K, Grawe F, Grzeschik N, Knust E (2002) Drosophila crumbs is required to inhibit lightinduced photoreceptor degeneration. Current Biology 12: 1675-1680. doi: 10.1016/S09609822(02)01180-6

Johnston RJ, Jr., Otake Y, Sood P, Vogt N, Behnia R, Vasiliauskas D, McDonald E, Xie B, Koenig S, Wolf R, Cook T, Gebelein B, Kussell E, Nakagoshi H, Desplan C (2011) Interlocked 
feedforward loops control cell-type-specific Rhodopsin expression in the Drosophila eye. Cell 145: 956-68. doi: 10.1016/j.cell.2011.05.003

Jonas JB, Schneider U, Naumann GO (1992) Count and density of human retinal photoreceptors. Graefes Arch Clin Exp Ophthalmol 230: 505-10.

Jordan T, Hanson I, Zaletayev D, Hodgson S, Prosser J, Seawright A, Hastie N, van Heyningen V (1992) The human PAX6 gene is mutated in two patients with aniridia. Nature Genetics 1: 328-332. doi: 10.1038/ng0892-328

Jun S, Wallen RV, Goriely a, Kalionis B, Desplan C (1998) Lune/eye gone, a Pax-like protein, uses a partial paired domain and a homeodomain for DNA recognition. Proceedings of the National Academy of Sciences of the United States of America 95: 13720-13725. doi: 10.1073/pnas.95.23.13720

Kaewkhaw R, Kaya KD, Brooks M, Homma K, Zou J, Chaitankar V, Rao M, Swaroop A (2015) Transcriptome Dynamics of Developing Photoreceptors in Three-Dimensional Retina Cultures Recapitulates Temporal Sequence of Human Cone and Rod Differentiation Revealing Cell Surface Markers and Gene Networks. Stem Cells 33: 3504-18. doi: $10.1002 /$ stem.2122

Kang M-J, Ryoo HD (2009) Suppression of retinal degeneration in Drosophila by stimulation of ERassociated degradation. Proceedings of the National Academy of Sciences of the United States of America 106: 17043-8. doi: 10.1073/pnas.0905566106

Kaplan J, Rozet J-M (2008) Eye Disorders: Hereditary. Encyclopedia of Life Sciences. doi: 10.1002/9780470015902.a0005510.pub2

Kenyon KL, Ranade SS, Curtiss J, Mlodzik M, Pignoni F (2003) Coordinating proliferation and tissue specification to promote regional identity in the Drosophila head. Dev Cell 5: 403-14.

Kiselev A, Socolich M, Vinós J, Hardy RW, Zuker CS, Ranganathan R (2000) A molecular pathway for light-dependent photoreceptor apoptosis in Drosophila. Neuron 28: 139-152. doi: 10.1016/S0896-6273(00)00092-1

Komatsu M, Waguri S, Chiba T, Murata S, Iwata JI, Tanida I, Ueno T, Koike M, Uchiyama Y, Kominami E, Tanaka K (2006) Loss of autophagy in the central nervous system causes neurodegeneration in mice. Nature 441: $880-884$. doi: 10.1038/nature04723 
Kozmik Z, Daube M, Frei E, Norman B, Kos L, Dishaw LJ, Noll M, Piatigorsky J (2003) Role of Pax genes in eye evolution: a cnidarian PaxB gene uniting Pax2 and Pax6 functions. Dev Cell 5: $773-85$.

Kreipke RE, Kwon YV, Shcherbata HR, Ruohola-Baker H (2017) Drosophila melanogaster as a Model of Muscle Degeneration Disorders. Curr Top Dev Biol 121: 83-109. doi: 10.1016/bs.ctdb.2016.07.003

Kristaponyte I, Hong Y, Lu H, Shieh B-H (2012) Role of Rhodopsin and Arrestin Phosphorylation in Retinal Degeneration of Drosophila. Journal of Neuroscience 32: 10758-10766. doi: 10.1523/JNEUROSCI.0565-12.2012

Kumar JP (2011) My what big eyes you have: how the Drosophila retina grows. Dev Neurobiol 71: 1133-52. doi: 10.1002/dneu.20921

Kumar JP (2012) Building an ommatidium one cell at a time. Dev Dyn 241: 136-49. doi: $10.1002 /$ dvdy.23707

Kumar JP (2018) The fly eye: Through the looking glass. Dev Dyn 247: 111-123. doi: $10.1002 / d v d y .24585$

Kumar JP, Moses K (2001) Expression of evolutionarily conserved eye specification genes during Drosophila embryogenesis. Dev Genes Evol 211: 406-14. doi: 10.1007/s004270100177

Kumar JP, Tio M, Hsiung F, Akopyan S, Gabay L, Seger R, Shilo BZ, Moses K (1998) Dissecting the roles of the Drosophila EGF receptor in eye development and MAP kinase activation. Development 125: 3875-85.

Kurada P, O'Tousa JE (1995) Retinal degeneration caused by dominant rhodopsin mutations in Drosophila. Neuron 14: 571-579. doi: 10.1016/0896-6273(95)90313-5

Kwon Y, Montell C (2006) Dependence on the Lazaro Phosphatidic Acid Phosphatase for the Maximum Light Response. Current Biology 16: 723-729. doi: 10.1016/j.cub.2006.02.057

LaLonde M, Janssens H, Yun S, Crosby J, Redina O, Olive V, Altshuller YM, Choi SY, Du G, Gergen JP, Frohman MA (2006) A role for Phospholipase D in Drosophila embryonic cellularization. BMC Developmental Biology 6: 1-13. doi: 10.1186/1471-213X-6-60

Land MF (2005) The optical structures of animal eyes. Curr Biol 15: R319-23. doi: 10.1016/j.cub.2005.04.041 
Latella MC, Di Salvo MT, Cocchiarella F, Benati D, Grisendi G, Comitato A, Marigo V, Recchia A (2016) In vivo Editing of the Human Mutant Rhodopsin Gene by Electroporation of Plasmidbased CRISPR/Cas9 in the Mouse Retina. Molecular Therapy - Nucleic Acids 5: e389. doi: 10.1038/mtna.2016.92

Laugier E, Yang Z, Fasano L, Kerridge S, Vola C (2005) A critical role of teashirt for patterning the ventral epidermis is masked by ectopic expression of tiptop, a paralog of teashirt in Drosophila. Dev Biol 283: 446-58. doi: 10.1016/j.ydbio.2005.05.005

Lee J, Song M, Hong S (2013) Negative Regulation of the Novel norpAP24 Suppressor, diehard4, in the Endo-lysosomal Trafficking Underlies Photoreceptor Cell Degeneration. PLoS Genetics 9. doi: 10.1371/journal.pgen.1003559

Lee JD, Treisman JE (2002) Regulators of the Morphogenetic Furrow. In: Moses K (ed) Drosophila Eye Development. Springer Berlin Heidelberg, Berlin, Heidelberg, pp 21-33

Lee JJ, von Kessler DP, Parks S, Beachy PA (1992) Secretion and localized transcription suggest a role in positional signaling for products of the segmentation gene hedgehog. Cell 71: 3350.

Lee RD, Thomas CF, Marietta RG, Stark WS (1996) Vitamin A, visual pigments, and visual receptors in Drosophila. Microscopy Research and Technique 35: 418-430. doi: 10.1002/(SICI)1097-0029(19961215)35:6<418::AID-JEMT2>3.0.CO;2-E

Leonard DS, Bowman VD, Ready DF, Pak WL (1992) Degeneration of photoreceptors in rhodopsin mutants of Drosophila. Journal of Neurobiology 23: 605-626. doi: $10.1002 /$ neu.480230602

Lewin AS, Rossmiller B, Mao H (2014) Gene augmentation for adRP mutations in RHO. Cold Spring Harbor Perspectives in Medicine 4: 1-13. doi: 10.1101/cshperspect.a017400

Li X, Oghi KA, Zhang J, Krones A, Bush KT, Glass CK, Nigam SK, Aggarwal AK, Maas R, Rose DW, Rosenfeld MG (2003) Eya protein phosphatase activity regulates Six1-Dach-Eya transcriptional effects in mammalian organogenesis. Nature 426: 247-254. doi: $10.1038 /$ nature02083

Li X, Perissi V, Liu F, Rose DW, Rosenfeld MG (2002) Tissue-specific regulation of retinal and pituitary precursor cell proliferation. Science 297: 1180-3. doi: 10.1126/science.1073263 
Liu C, Li Y, Peng M, Laties AM, Wen R (1999) Activation of caspase-3 in the retina of transgenic rats with the rhodopsin mutation s334ter during photoreceptor degeneration. J Neurosci 19: 4778-85.

Lotery AJ, Jacobson SG, Fishman GA, Weleber RG, Fulton AB, Namperumalsamy P, Heon E, Levin AV, Grover S, Rosenow JR, Kopp KK, Sheffield VC, Stone EM (2001) Mutations in the CRB1 gene cause Leber congenital amaurosis. Arch Ophthalmol 119: 415-20.

Mao H, James T, Schwein A, Shabashvili AE, Hauswirth WW, Gorbatyuk MS, Lewin AS (2011) AAV Delivery of Wild-Type Rhodopsin Preserves Retinal Function in a Mouse Model of Autosomal Dominant Retinitis Pigmentosa. Human Gene Therapy 22: 567-575. doi: 10.1089/hum.2010.140

Mardon G, Solomon NM, Rubin GM (1994) dachshund encodes a nuclear protein required for normal eye and leg development in Drosophila. Development (Cambridge, England) 120: 3473-3486.

Masai I, Okazakit A, Hosoyat T, Hottatt Y (1993) Drosophila retinal degeneration A gene encodes an eye-specific diacylglycerol kinase with cysteine-rich zinc-finger motifs and ankyrin repeats (signal transduction/phosphatidylinositol metabolism). Neurobiology 90: 1115711161. doi: 10.1073/pnas.90.23.11157

Masai I, Stemple DL, Okamoto H, Wilson SW (2000) Midline signals regulate retinal neurogenesis in zebrafish. Neuron 27: 251-63.

Maw MA, Corbeil D, Koch J, Hellwig A, Wilson-Wheeler JC, Bridges RJ, Kumaramanickavel G, John S, Nancarrow D, Röper K, Weigmann A, Huttner WB, Denton MJ (2000) A frameshift mutation in prominin (mouse)-like 1 causes human retinal degeneration. Human molecular genetics 9: 27-34. doi: Doi 10.1093/Hmg/9.1.27

McKay GJ, Clarke S, Davis JA, Simpson DAC, Silvestri G (2005) Pigmented paravenous chorioretinal atrophy is associated with a mutation within the crumbs homolog 1 (CRB1) gene. Investigative Ophthalmology and Visual Science 46: 322-328. doi: 10.1167/iovs.040734

Meyertholen EP, Stein PJ, Williams MA, Ostroy SE (1987) Studies of the Drosopbila norpA phototransduction mutant. 793-798. 
Michno K, van de Hoef D, Wu H, Boulianne GL (2005) Modeling age-related diseases in Drosophila: can this fly? Curr Top Dev Biol 71: 199-223. doi: 10.1016/s00702153(05)71006-1

Myers EW, Sutton GG, Delcher AL, Dew IM, Fasulo DP, Flanigan MJ, Kravitz SA, Mobarry CM, Reinert $\mathrm{KH}$, Remington KA, Anson EL, Bolanos RA, Chou HH, Jordan CM, Halpern AL, Lonardi S, Beasley EM, Brandon RC, Chen L, Dunn PJ, Lai Z, Liang Y, Nusskern DR, Zhan M, Zhang Q, Zheng X, Rubin GM, Adams MD, Venter JC (2000) A whole-genome assembly of Drosophila. Science 287: 2196-204.

Nathans J, Weitz CJ, Agarwal N, Nir I, Papermaster DS (1989) Production of bovine rhodopsin by mammalian cell lines expressing cloned cDNA: spectrophotometry and subcellular localization. Vision Res 29: 907-14.

Neumann CJ, Nuesslein-Volhard C (2000) Patterning of the zebrafish retina by a wave of sonic hedgehog activity. Science 289: 2137-9.

Nie J, Mahato S, Mustill W, Tipping C, Bhattacharya SS, Zelhof AC (2012) Cross species analysis of Prominin reveals a conserved cellular role in invertebrate and vertebrate photoreceptor cells. Developmental Biology 371: 312-320. doi: 10.1016/j.ydbio.2012.08.024

Niimi T, Seimiya M, Kloter U, Flister S, Gehring WJ (1999) Direct regulatory interaction of the eyeless protein with an eye-specific enhancer in the sine oculis gene during eye induction in Drosophila. Development (Cambridge, England) 126: 2253-60.

Orem NR, Dolph PJ (2002) Loss of the phospholipase C gene product induces massive endocytosis of rhodopsin and arrestin in Drosophila photoreceptors. Vision Research 42: 497-505. doi: 10.1016/S0042-6989(01)00229-2

Orrenius S, Zhivotovsky B, Nicotera P (2003) Regulation of cell death: The calcium-apoptosis link. Nature Reviews Molecular Cell Biology 4: 552-565. doi: 10.1038/nrm1150

Ostrin EJ (2006) Genome-wide identification of direct targetsof the Drosophila retinal determinationprotein Eyeless. Genome Research 16: 466-476. doi: 10.1101/gr.4673006

Papatsenko D, Nazina A, Desplan C (2001) A conserved regulatory element present in all Drosophila rhodopsin genes mediates Pax6 functions and participates in the fine-tuning of 
cell-specific expression. Mechanisms of Development 101: 143-153. doi: 10.1016/S09254773(00)00581-5

Papayannopoulos V, Tomlinson A, Panin VM, Rauskolb C, Irvine KD (1998) Dorsal-ventral signaling in the Drosophila eye. Science 281: 2031-4.

Pappu KS (2005) Dual regulation and redundant function of two eye-specific enhancers of the Drosophila retinal determination gene dachshund. Development 132: 2895-2905. doi: 10.1242/dev.01869

Patterson JT, Muller HJ (1930) Are "Progressive" Mutations Produced by X-Rays? Genetics 15: 495-577.

Pellikka M, Tanentzapf M, Pinto M, Smith C, McGlade CJ, Ready DF, Tepass U (2002) Crumbs, the Drosophlia homologue of human CRB1/RP12, is essential for photoreceptor morhogenesis. Nature 416.

Peng GH, Ahmad O, Ahmad F, Liu J, Chen S (2005) The photoreceptor-specific nuclear receptor $\mathrm{Nr2e} 3$ interacts with Crx and exerts opposing effects on the transcription of rod versus cone genes. Hum Mol Genet 14: 747-64. doi: 10.1093/hmg/ddi070

Pepple KL, Atkins M, Venken K, Wellnitz K, Harding M, Frankfort B, Mardon G (2008) Two-step selection of a single R8 photoreceptor: a bistable loop between senseless and rough locks in R8 fate. Development 135: 4071-9. doi: 10.1242/dev.028951

Pichaud F, Casares F (2000) homothorax and iroquois-C genes are required for the establishment of territories within the developing eye disc. Mech Dev 96: 15-25.

Pignoni F, Hu B, Zavitz KH, Xiao J, Garrity PA, Zipursky SL (1997) The eye-specification proteins So and Eya form a complex and regulate multiple steps in Drosophila eye development. Cell 91: 881-891. doi: 10.1016/S0092-8674(00)80480-8

Pocha SM, Shevchenko A, Knust E (2011) Crumbs regulates rhodopsin transport by interacting with and stabilizing myosin V. Journal of Cell Biology 195: 827-838. doi: 10.1083/jcb.201105144

Posnien N, Hopfen C, Hilbrant M, Ramos-Womack M, Murat S, Schonauer A, Herbert SL, Nunes MD, Arif S, Breuker CJ, Schlotterer C, Mitteroecker P, McGregor AP (2012) Evolution of 
eye morphology and rhodopsin expression in the Drosophila melanogaster species subgroup. PLoS One 7: e37346. doi: 10.1371/journal.pone.0037346

Punzo C (2004) Functional divergence between eyeless and twin of eyeless in Drosophila melanogaster. Development 131: 3943-3953. doi: 10.1242/dev.01278

Punzo C, Kurata S, Gehring WJ (2001) The eyeless homeodomain is dispensable for eye development in Drosophila. Genes and Development 15: 1716-1723. doi: 10.1101/gad.196401

Quiring R, Walldorf U, Kloter U, Gehring W (1994) Homology of the eyeless gene of Drosophila to the Small eye gene in mice and Aniridia in humans. Science 265: 785-789. doi: 10.1126/science. 7914031

Ragge NK, Brown AG, Poloschek CM, Lorenz B, Henderson RA, Clarke MP, Russell-Eggitt I, Fielder A, Gerrelli D, Martinez-Barbera JP, Ruddle P, Hurst J, Collin JR, Salt A, Cooper ST, Thompson PJ, Sisodiya SM, Williamson KA, Fitzpatrick DR, van Heyningen V, Hanson IM (2005) Heterozygous mutations of OTX2 cause severe ocular malformations. Am J Hum Genet 76: 1008-22. doi: 10.1086/430721

Raghu P, Usher K, Jonas S, Chyb S, Polyanovsky A, Hardie RC (2000) Constitutive activity of the light-sensitive channels TRP and TRPL in the Drosophila diacylglycerol kinase mutant, rdgA. Neuron 26: 169-179. doi: 10.1016/S0896-6273(00)81147-2

Raymond PA, Barthel LK (2004) A moving wave patterns the cone photoreceptor mosaic array in the zebrafish retina. Int J Dev Biol 48: 935-45. doi: 10.1387/ijdb.041873pr

Reiter LT, Potocki L, Chien S, Gribskov M, Bier E (2001) A systematic analysis of human diseaseassociated gene sequences in Drosophila melanogaster. Genome Res 11: 1114-25. doi: 10.1101/gr.169101

Richard M, Grawe F, Knust E (2006) DPATJ plays a role in retinal morphogenesis and protects against light-dependent degeneration of photoreceptor cells in the Drosophila eye. Developmental Dynamics 235: 895-907. doi: 10.1002/dvdy.20595

Roessler E, Belloni E, Gaudenz K, Jay P, Berta P, Scherer SW, Tsui LC, Muenke M (1996) Mutations in the human Sonic Hedgehog gene cause holoprosencephaly. Nat Genet 14: 357-60. doi: 10.1038/ng1196-357 
Rosenbaum EE, Brehm KS, Vasiljevic E, Liu CH, Hardie RC, Colley NJ (2011) XPORT-Dependent Transport of TRP and Rhodopsin. Neuron 72: 602-615. doi: 10.1016/j.neuron.2011.09.016

Rosenbaum EE, Hardie RC, Colley NJ (2006) Calnexin is essential for rhodopsin maturation, Ca2+ regulation, and photoreceptor cell survival. Neuron 49: 229-241. doi: 10.1016/j.neuron.2005.12.011

Rubin GM, Lewis EB (2000) A brief history of Drosophila's contributions to genome research. Science 287: 2216-8.

Salzer CL, Kumar JP (2009) Position dependent responses to discontinuities in the retinal determination network. Developmental Biology 326: 121-130. doi: 10.1016/j.ydbio.2008.10.048

Sanes JR, Zipursky SL (2010) Design principles of insect and vertebrate visual systems. Neuron 66: 15-36. doi: 10.1016/j.neuron.2010.01.018

Sanyanusin P, Schimmenti LA, McNoe LA, Ward TA, Pierpont ME, Sullivan MJ, Dobyns WB, Eccles MR (1995) Mutation of the PAX2 gene in a family with optic nerve colobomas, renal anomalies and vesicoureteral reflux. Nat Genet 9: 358-64. doi: 10.1038/ng0495-358

Sen A, Cox RT (2017) Fly Models of Human Diseases: Drosophila as a Model for Understanding Human Mitochondrial Mutations and Disease. Curr Top Dev Biol 121: 1-27. doi: 10.1016/bs.ctdb.2016.07.001

Senturk M, Bellen HJ (2017) Genetic strategies to tackle neurological diseases in fruit flies. Curr Opin Neurobiol 50: 24-32. doi: 10.1016/j.conb.2017.10.017

Shen W, Mardon G (1997) Ectopic eye development in Drosophila induced by directed dachshund expression. Development (Cambridge, England) 124: 45-52.

Sheng G, Thouvenot E, Schmucker D, Wilson DS, Desplan C (1997) Direct regulation of rhodopsin 1 by Pax-6/eyeless in Drosophila: Evidence for a conserved function in photoreceptors. Genes and Development 11: 1122-1131. doi: 10.1101/gad.11.9.1122

Shokravi MT, Dryja TP (1993) Retinitis pigmentosa and the rhodopsin gene. Int Ophthalmol Clin 33: $219-28$.

Sobreira N, Schiettecatte F, Boehm C, Valle D, Hamosh A (2015a) New tools for Mendelian disease gene identification: PhenoDB variant analysis module; and GeneMatcher, a web- 
based tool for linking investigators with an interest in the same gene. Hum Mutat 36: 42531. doi: 10.1002/humu.22769

Sobreira N, Schiettecatte F, Valle

D, Hamosh A (2015b) GeneMatcher: a matching tool for connecting investigators with an interest in the same gene. Hum Mutat 36: 928-30. doi: 10.1002/humu.22844

Sohocki MM, Sullivan LS, Mintz-Hittner HA, Birch D, Heckenlively JR, Freund CL, Mclnnes RR, Daiger SP (1998) A range of clinical phenotypes associated with mutations in CRX, a photoreceptor transcription-factor gene. Am J Hum Genet 63: 1307-15. doi: $10.1086 / 302101$

Sonoshita M, Cagan RL (2017) Modeling Human Cancers in Drosophila. Curr Top Dev Biol 121: 287-309. doi: 10.1016/bs.ctdb.2016.07.008

Stark WS, Sapp R (1987) Ultrastructure of the retina of drosophila melanogaster. The mutant ora (outer rhabdomeres absent) and its inhibition of degeneration in rdgb (retinal degenerationb). Journal of Neurogenetics 4: 227-240. doi: 10.3109/01677068709102343

Steele F, O'Tousa JE (1990) Rhodopsin activation causes retinal degeneration in drosophila rdgC mutant. Neuron 4: 883-890. doi: 10.1016/0896-6273(90)90141-2

Sun Y, Kanekar SL, Vetter ML, Gorski S, Jan YN, Glaser T, Brown NL (2003) Conserved and divergent functions of Drosophila atonal, amphibian, and mammalian Ath5 genes. Evol Dev 5: 532-41.

Sundaram K, Mani SK, Kitatani K, Wu K, Pestell RG, Reddy SV (2008) DACH1 negatively regulates the human RANK ligand gene expression in stromal/preosteoblast cells. Journal of Cellular Biochemistry 103: 1747-1759. doi: 10.1002/jcb.21561

Sung CH, Davenport CM, Nathans J (1993) Rhodopsin mutations responsible for autosomal dominant retinitis pigmentosa. Clustering of functional classes along the polypeptide chain. Journal of Biological Chemistry 268: 26645-26649.

Tahayato A, Sonneville R, Pichaud F, Wernet MF, Papatsenko D, Beaufils P, Cook T, Desplan C (2003) Otd/Crx, a dual regulator for the specification of ommatidia subtypes in the Drosophila retina. Dev Cell 5: 391-402. 
Terrell D, Xie B, Workman M, Mahato S, Zelhof A, Gebelein B, Cook T (2012a) OTX2 and CRX rescue overlapping and photoreceptor-specific functions in the Drosophila eye. Dev Dyn 241: 215-28. doi: $10.1002 / d v d y .22782$

Terrell D, Xie B, Workman M, Mahato S, Zelhof A, Gebelein B, Cook T (2012b) OTX2 and CRX rescue overlapping and photoreceptor-specific functions in the Drosophila eye. Developmental Dynamics 241: 215-228. doi: 10.1002/dvdy.22782

Ton CCT, Hirvonen H, Miwa H, Weil MM, Monaghan P, Jordan T, van Heyningen V, Hastie ND, Meijers-Heijboer H, Drechsler M, Royer-Pokora B, Collins F, Swaroop A, Strong LC, Saunders GF (1991) Positional cloning and characterization of a paired box- and homeobox-containing gene from the aniridia region. Cell 67: 1059-1074. doi: 10.1016/00928674(91)90284-6

Toy J, Norton JS, Jibodh SR, Adler R (2002) Effects of homeobox genes on the differentiation of photoreceptor and nonphotoreceptor neurons. Invest Ophthalmol Vis Sci 43: 3522-9.

Treisman JE (1999) A conserved blueprint for the eye? BioEssays 21: 843-850. doi: 10.1002/(SICI)1521-1878(199910)21:10<843::AID-BIES6>3.0.CO;2-J

Treisman JE (2013) Retinal differentiation in Drosophila. Wiley Interdiscip Rev Dev Biol 2: 545-57. doi: $10.1002 /$ wdev.100

Voolstra O, Oberhauser V, Sumser E, Meyer NE, Maguire ME, Huber A, Von Lintig J (2010) NinaB is essential for Drosophila vision but induces retinal degeneration in opsin-deficient photoreceptors. Journal of Biological Chemistry 285: 2130-2139. doi: 10.1074/jbc.M109.056101

Vopalensky P, Kozmik Z (2009) Eye evolution: common use and independent recruitment of genetic components. Philos Trans R Soc Lond B Biol Sci 364: 2819-32. doi: $10.1098 /$ rstb.2009.0079

Wallis DE, Roessler E, Hehr U, Nanni L, Wiltshire T, Richieri-Costa A, Gillessen-Kaesbach G, Zackai EH, Rommens J, Muenke M (1999) Mutations in the homeodomain of the human SIX3 gene cause holoprosencephaly. Nat Genet 22: 196-8. doi: 10.1038/9718

Wang SZ, Adler R, Nathans J (1992) A visual pigment from chicken that resembles rhodopsin: amino acid sequence, gene structure, and functional expression. Biochemistry 31: 3309-15. 
Wang T, Lao U, Edgar BA (2009) TOR-mediated autophagy regulates cell death in $<i>$ Drosophila</i> neurodegenerative disease. The Journal of Cell Biology 186: 703-711. doi: $10.1083 / j c b .200904090$

Wang T, Montell C (2007) Phototransduction and retinal degeneration in Drosophila. Pflugers Archiv European Journal of Physiology 454: 821-847. doi: 10.1007/s00424-007-0251-1

Wang T, Xu H, Oberwinkler J, Gu Y, Hardie RC, Montell C (2005) Light activation, adaptation, and cell survival functions of the $\mathrm{Na}+/ \mathrm{Ca} 2+$ exchanger CalX. Neuron 45: 367-78. doi: 10.1016/j.neuron.2004.12.046

Wang X, Wang T, Jiao Y, von Lintig J, Montell C (2010) Requirement for an Enzymatic Visual Cycle in Drosophila. Current Biology 20: 93-102. doi: 10.1016/j.cub.2009.12.022

Wang X, Wang T, Ni JD, von Lintig J, Montell C (2012) The Drosophila visual cycle and de novo chromophore synthesis depends on rdhB. J Neurosci 32: 3485-91. doi: 10.1523/jneurosci.5350-11.2012

Wangler MF, Yamamoto S, Bellen HJ (2015) Fruit flies in biomedical research. Genetics 199: 63953. doi: $10.1534 /$ genetics. 114.171785

Wangler MF, Yamamoto S, Chao HT, Posey JE, Westerfield M, Postlethwait J, Hieter P, Boycott KM, Campeau PM, Bellen HJ (2017) Model Organisms Facilitate Rare Disease Diagnosis and Therapeutic Research. Genetics 207: 9-27. doi: 10.1534/genetics.117.203067

Warburg M (1993) Classification of microphthalmos and coloboma. J Med Genet 30: 664-9.

Wawersik S, Maas RL (2000) Vertebrate eye development as modeled in Drosophila. Hum Mol Genet 9: 917-25.

Weasner B, Salzer C, Kumar JP (2007) Sine oculis, a member of the SIX family of transcription factors, directs eye formation. Dev Biol 303: 756-71. doi: 10.1016/j.ydbio.2006.10.040

Wernet MF, Mazzoni EO, Celik A, Duncan DM, Duncan I, Desplan C (2006) Stochastic spineless expression creates the retinal mosaic for colour vision. Nature 440: 174-80. doi: 10.1038/nature04615

Williamson KA, FitzPatrick DR (2014) The genetic architecture of microphthalmia, anophthalmia and coloboma. Eur J Med Genet 57: 369-80. doi: 10.1016/j.ejmg.2014.05.002 
Wu K, Jiao X, Li Z, Katiyar S, Casimiro MC, Yang W, Zhang Q, Willmarth NE, Chepelev I, Crosariol M, Wei Z, Hu J, Zhao K, Pestell RG (2011) Cell fate determination factor Dachshund reprograms breast cancer stem cell function. Journal of Biological Chemistry 286: 2132-2142. doi: 10.1074/jbc.M110.148395

Wu K, Katiyar S, Li A, Liu M, Ju X, Popov VM, Jiao X, Lisanti MP, Casola A, Pestell RG (2008) Dachshund inhibits oncogene-induced breast cancer cellular migration and invasion through suppression of interleukin-8. Proceedings of the National Academy of Sciences of the United States of America 105: 6924-6929. doi: 10.1073/pnas.0802085105

Wu K, Katiyar S, Witkiewlcz A, Li A, Mccue P, Song LN, Tian L, Jin M, Pestell RG (2009) The cell fate Determination factor Dachshund inhibits androgen receptor signaling and prostate cancer cellular growth. Cancer Research 69: 3347-3355. doi: 10.1158/0008-5472.CAN-083821

Wu K, Li A, Rao M, Liu M, Dailey V, Yang Y, Di Vizio D, Wang C, Lisanti MP, Sauter G, Russell RG, Cvekl A, Pestell RG (2006) DACH1 Is a Cell Fate Determination Factor That Inhibits Cyclin D1 and Breast Tumor Growth. Molecular and Cellular Biology 26: 7116-7129. doi: 10.1128/MCB.00268-06

Wu K, Yang Y, Wang C, Davoli MA, D'Amico M, Li A, Cveklova K, Kozmik Z, Lisanti MP, Russell RG, Cvekl A, Pestell RG (2003) DACH1 Inhibits Transforming Growth Factor- $\beta$ Signaling through Binding Smad4. Journal of Biological Chemistry 278: 51673-51684. doi: 10.1074/jbc.M310021200

Xiong B, Bellen HJ (2013) Rhodopsin homeostasis and retinal degeneration: Lessons from the fly. Trends in Neurosciences 36: 652-660. doi: 10.1016/j.tins.2013.08.003

Xu PX, Zhang X, Heaney S, Yoon a, Michelson aM, Maas RL (1999) Regulation of Pax6 expression is conserved between mice and flies. Development (Cambridge, England) 126: 383-395.

Xu Q, Wang Y, Dabdoub A, Smallwood PM, Williams J, Woods C, Kelley MW, Jiang L, Tasman W, Zhang K, Nathans J (2004) Vascular development in the retina and inner ear: control by Norrin and Frizzled-4, a high-affinity ligand-receptor pair. Cell 116: 883-95. 
Yamamoto S, Jaiswal M, Charng WL, Gambin T, Karaca E, Mirzaa G, Wiszniewski W, Sandoval H, Haelterman NA, Xiong B, Zhang K, Bayat V, David G, Li T, Chen K, Gala U, Harel T, Pehlivan D, Penney S, Vissers L, de Ligt J, Jhangiani SN, Xie Y, Tsang SH, Parman Y, Sivaci M, Battaloglu E, Muzny D, Wan YW, Liu Z, Lin-Moore AT, Clark RD, Curry CJ, Link N, Schulze KL, Boerwinkle E, Dobyns WB, Allikmets R, Gibbs RA, Chen R, Lupski JR, Wangler MF, Bellen HJ (2014) A drosophila genetic resource of mutants to study mechanisms underlying human genetic diseases. Cell 159: 200-214. doi: 10.1016/j.cell.2014.09.002

Yan J, Anderson C, Viets K, Tran S, Goldberg G, Small S, Johnston RJ, Jr. (2017) Regulatory logic driving stable levels of defective proventriculus expression during terminal photoreceptor specification in flies. Development 144: 844-855. doi: 10.1242/dev.144030

Yao JG, Sun YH (2005) Eyg and Ey Pax proteins act by distinct transcriptional mechanisms in Drosophila development. EMBO Journal 24: 2602-2612. doi: 10.1038/sj.emboj.7600725

Yoon J, Ben-Ami HC, Hong YS, Park S, Strong LL, Bowman J, Geng C, Baek K, Minke B, Pak WL (2000) Novel mechanism of massive photoreceptor degeneration caused by mutations in the trp gene of Drosophila. The Journal of neuroscience : the official journal of the Society for Neuroscience 20: 649-659.

Younossi-Hartenstein A, Tepass U, Hartenstein V (1993) Embryonic origin of the imaginal discs of the head of Drosophila melanogaster. Roux Arch Dev Biol 203: 60-73. doi: $10.1007 / \mathrm{bf00539891}$

Yu M, Liu Y, Li J, Natale BN, Cao S, Wang D, Amack JD, Hu H (2016) Eyes shut homolog is required for maintaining the ciliary pocket and survival of photoreceptors in zebrafish. Biology Open 5: 1662-1673. doi: 10.1242/bio.021584

Yu W, Mookherjee S, Chaitankar V, Hiriyanna S, Kim JW, Brooks M, Ataeijannati Y, Sun X, Dong L, Li T, Swaroop A, Wu Z (2017) Nrl knockdown by AAV-delivered CRISPR/Cas9 prevents retinal degeneration in mice. Nature Communications 8: 1-15. doi: 10.1038/ncomms14716

Zelhof AC, Hardy RW, Becker A, Zuker CS (2006) Transforming the architecture of compound eyes. Nature 443: 696-699. doi: 10.1038/nature05128 
1 Zhang T, Ranade S, Cai CQ, Clouser C, Pignoni F (2006) Direct control of neurogenesis by selector factors in the fly eye: regulation of atonal by Ey and So. Development 133: 48814889. doi: $10.1242 /$ dev.02669

4 Zhao F, Wang M, Li S, Bai X, Bi H, Liu Y, Ao X, Jia Z, Wu H (2015) DACH1 inhibits SNAl1mediated epithelial-mesenchymal transition and represses breast carcinoma metastasis. Oncogenesis 4: 1-14. doi: 10.1038/oncsis.2015.3

7 Zhou Q, Zhang T, Jemc JC, Chen Y, Chen R, Rebay I, Pignoni F (2014) Onset of atonal 8 expression in Drosophila retinal progenitors involves redundant and synergistic contributions of Ey/Pax6 and So binding sites within two distant enhancers. Developmental Biology 386: 152-164. doi: 10.1016/j.ydbio.2013.11.012

11 Zuber ME (2003) Specification of the vertebrate eye by a network of eye field transcription factors. 


\section{Figure legends}

2 Figure 1. Comparative overview of human and Drosophila eye development. Eye

3 development from week 4 to week 20 of human embryogenesis a. At week 4 of

4 development, the optic vesicles evaginate from the forebrain neuroectoderm inducing the

5 adjacent ectoderm to form the lens placode. Between weeks 4 and 6 , the optic vesicle

6 invaginates on itself, forming the optic cup, which partially encapsulates the invaginating

7 lens vesicle (interrupted posteriorly by the optic fissure). After week 6 and until week 20 ,

8 the optic cup differentiates into two main layers, the neuroretina and the pigmented

9 epithelium, while the lens vesicle thickens and forms the crystalline lens. The neural cells

10 in the neuroretina differentiate from the center to the periphery of the optic disc, such that

11 the adult retina pattern is set with circumferential bands or zones enriched in specific

12 photoreceptors. Eye development and adult retina patterning of Drosophilab. The eye

13 imaginal disc develops from an invagination of the embryonic ectoderm, being subdivided

14 early to form precursor regions to the eye and antenna (1st larval instar imaginal disc).

15 During the 3rd larval instar, differentiation of ommatidia into clusters of 8 photoreceptor

16 cells progresses from the posterior to the anterior of the disc, as a band of apical cell

17 constrictions termed the morphogenetic furrow sweeps across the tissue. The longitudinal

18 structure of the adult ommatidium shows an apical facet lens lined basally by primary

19 pigment cells and focusing into a central rhabdomere projected by the lateral membrane of

20 the photoreceptor cells. The cluster of photoreceptor cells is surrounded by secondary and

21 tertiary pigment cells. The adult retina is patterned dorso-ventrally into two main zones, a

22 dorsal third consisting of the dorsal rim area and dorsal yellow ommatidia, and a ventral

23 area with a stochastic pattern of yellow and pale ommatidia. Ommatidia in these areas

24 have a specific repertoire of rhodopsin (Rh) gene expression in photoreceptors $\mathrm{R} 7$ and $\mathrm{R} 8$

25 (A—anterior, P—posterior, D—dorsal, V—ventral, R—photoreceptor, Rh-rhodopsin) 
2 Figure 2. Drosophila melanogaster eye development. (A-B) Drosophila adult head (A) and eye-antennal imaginal disc stained with anti-Eya (magenta), DAPI (blue) and phalloidinAlexaFluor488 (Green) (B). Colour code represents the larval structures that will give rise to the adult structures of the head: compound eye (CE, magenta), ocelli (oc, dark

6 magenta), antenna (a, dark green), maxillary palp ( $\mathrm{mp}$, light green), and head capsule (hc,

7 blue). (C) Section of an eye imaginal disc showing the compartments where proliferation 8 (most anterior), determination (around MF) and specification (posterior to MF) are 9 occurring. From anterior to posterior (left to right): progenitors are characterised by high 10 levels of proliferation (mitotic cells in red), followed by synchronic cells at G1, the First 11 Mitotic Wave (FMW), Morphogenetic Furrow (MF), cells differentiating (second mitotic wave, SMW) into ommatidia most posteriorly. Mitotic cells are stained using an anti-PH3 antibody (red), MF is marked with Phalloidin-AlexaFluor488 (green) and Photoreceptors are shown using anti-Elav, in blue. A simplified gene network showing the main molecules involved in the three processes is displayed. Colour code highlights the process in which each molecule has its main role. Scale bar $50 \mu \mathrm{m}$. All the panels show anterior to the left

17 and posterior to the right.

Figure 3. The Drosophila phototransduction apparatus. The Drosophila compound eye (A) is composed of hundreds of ommatidia units $(B)$ made up of a cluster of 8 photoreceptor

21 cells surrounded by pigment cells and mechanosensory bristles. Each photoreceptor cell 22 projects a microvilli dense membrane towards the centre of the ommatidium, making up 23 the light-sensitive rhabdomere $(C)$. The rhabdomere membrane is supported at its base by 24 the Crumbs/PatJ/Stardust complex and at its core by the structural proteins Chaoptin, 25 Prominin and Eyes Shut. Within the rhabdomere membrane (D), the phototransduction cascade is initiated by the light-induced conformational change of Rhodopsin into 
1 Metarhodopsin, which in turn is able to become phosphorylated by GPRK1, interact with a

2 Gaq protein and bind Arrestin2. This initiates a series of other reactions, from the

3 conversion of PIP2 into IP3 and DAG to the internalisation of Metarhodopsin-Arrestin

4 complexes. DAG is able to stimulate $\mathrm{Ca}^{2+}$ influx via TRP channels, which in turn can be

5 counterbalanced by $\mathrm{Ca}^{2+} / \mathrm{Na}^{+}$antiport by the CalX channel. Light-induced conformational

6 change of Metarhodopsin can promote its dephosphorylation by RdgC and

7 phosphorylation of Arrestin2 by CAMKII, which promotes its dissociation, thus ensuing the 8 recycling of Rhodopsin's original state. 
Table 1.

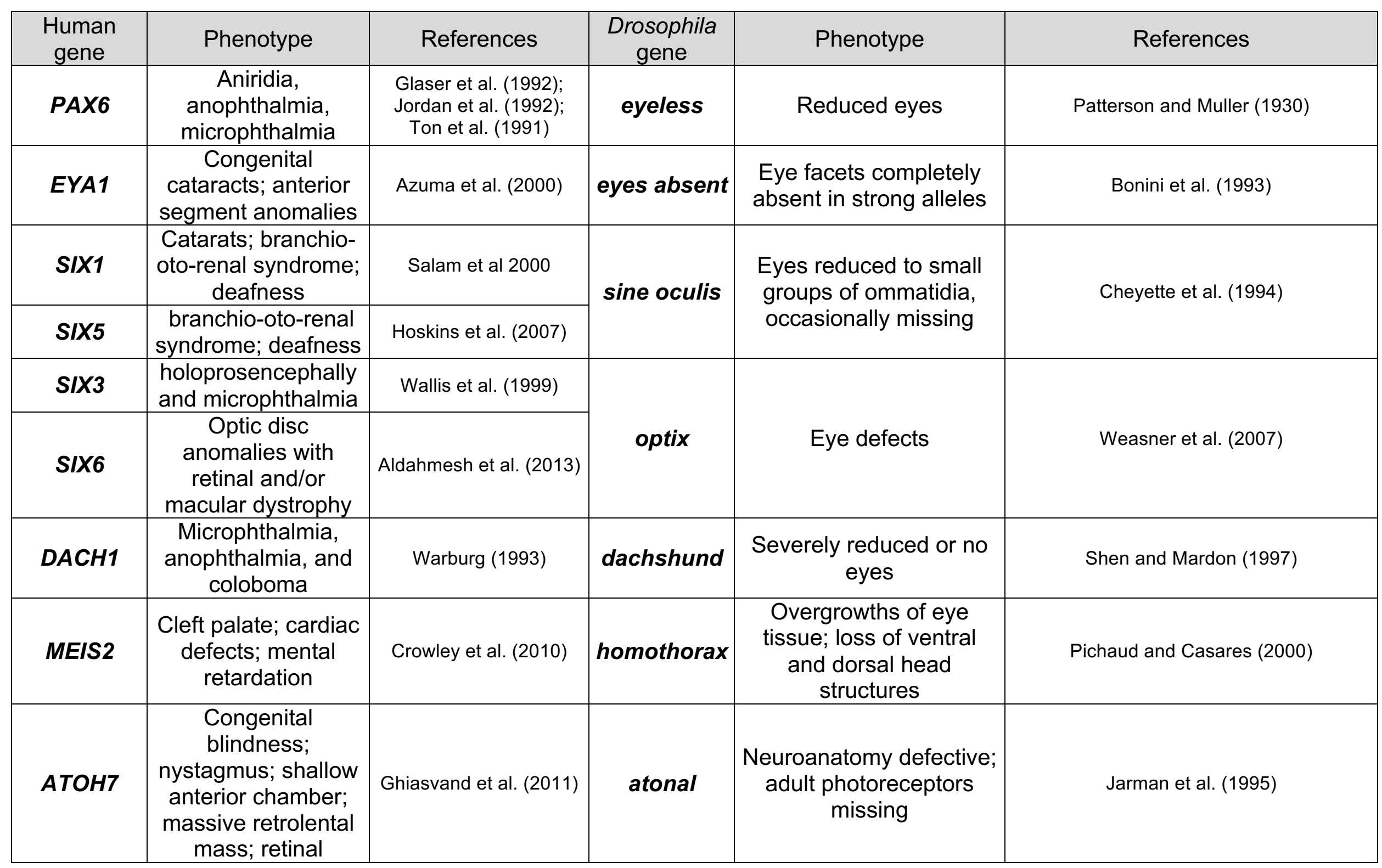




\begin{tabular}{|c|c|c|c|c|c|}
\hline & nonattachment & & & & \\
\hline OTX2 & $\begin{array}{c}\text { Microphthalmia, } \\
\text { syndromic 5; Retinal } \\
\text { dystrophy; Early- } \\
\text { onset, with or } \\
\text { without pituitary } \\
\text { dysfunction; Cone- } \\
\text { rod retinal } \\
\text { dystrophy-2 }\end{array}$ & $\begin{array}{l}\text { Freund et al. (1997); } \\
\text { Ragge et al. (2005) }\end{array}$ & \multirow[t]{2}{*}{$O C$} & \multirow[t]{2}{*}{$\begin{array}{l}\text { Eyes somewhat reduced } \\
\text { and body size dwarfed. } \\
\text { Phototaxis normal }\end{array}$} & \multirow[t]{2}{*}{ Benzer (1967) } \\
\hline$C R X$ & $\begin{array}{l}\text { cone-rod dystrophy; } \\
\text { retinitis pigmentosa; } \\
\text { LCA }\end{array}$ & $\begin{array}{l}\text { Freund et al. (1997); } \\
\text { Freund et al. (1998); } \\
\text { Sohocki et al. (1998) }\end{array}$ & & & \\
\hline CRB1 & \begin{tabular}{|c|} 
Pigmented \\
paravenous \\
chorioretinal \\
atrophy; Retinitis \\
pigmentosa-12, \\
autosomal recessive \\
\end{tabular} & $\begin{array}{l}\text { Den Hollander et al. } \\
\text { (1999) }\end{array}$ & Crumbs & $\begin{array}{l}\text { Mild overgrowth of adult } \\
\text { eyes }\end{array}$ & Chen Ling, ... Pan 2010 \\
\hline EYS & $\begin{array}{c}\text { Retinitis pigmentosa } \\
25\end{array}$ & Abd El-Aziz et al. (2008) & Eyes Shut & Rhabdomere defects & Zelhof et al. (2006) \\
\hline PAX2 & $\begin{array}{l}\text { optic nerve } \\
\text { coloboma }\end{array}$ & $\begin{array}{l}\text { Favor et al. (1996); } \\
\text { Sanyanusin et al. } \\
(1995)\end{array}$ & D-Pax2 & $\begin{array}{l}\text { Eyes small, rough, and } \\
\text { glazed }\end{array}$ & Fu et al. (1998) \\
\hline $\mathrm{SHH}$ & holoprosencephally & Roessler et al. (1996) & hedgehog & $\begin{array}{l}\text { Eye small and narrow } \\
\text { with about } 150 \text { facets }\end{array}$ & $\begin{array}{c}\text { Lee et al. (1992) } \\
\text {;Renfranz and Benzer, 1989, Dev. Biol. } \\
\text { 136: 411-29). Heberlein et al, Nature } \\
1995\end{array}$ \\
\hline RHO & $\begin{array}{l}\text { Autossomal } \\
\text { dominant retinitis } \\
\text { pigmentosa }\end{array}$ & $\begin{array}{l}\text { Bhattacharya et al. (); } \\
\text { Dryja et al. (1991); } \\
\text { Dryja et al. (1990) }\end{array}$ & ninaE & $\begin{array}{l}\text { rhabdomeres 1-6 is } \\
\text { smaller than normal; } \\
\text { light-independent } \\
\text { degeneration of R1-6 } \\
\text { rhabdomeres }\end{array}$ & $\begin{array}{l}\text { Kurada and O'Tousa (1995) } \\
\text { Colley et al, PNAS, 1995; }\end{array}$ \\
\hline PROMININ-1 & $\begin{array}{l}\text { autosomal recessive } \\
\text { retinal degeneration }\end{array}$ & Maw et al. (2000) & Prominin & $\begin{array}{c}\text { defective photoreceptor } \\
\text { morphogenesis;disrupted } \\
\text { interrabdomeral space }\end{array}$ & Zelhof et al. (2006) \\
\hline
\end{tabular}




\section{A Human eye development}
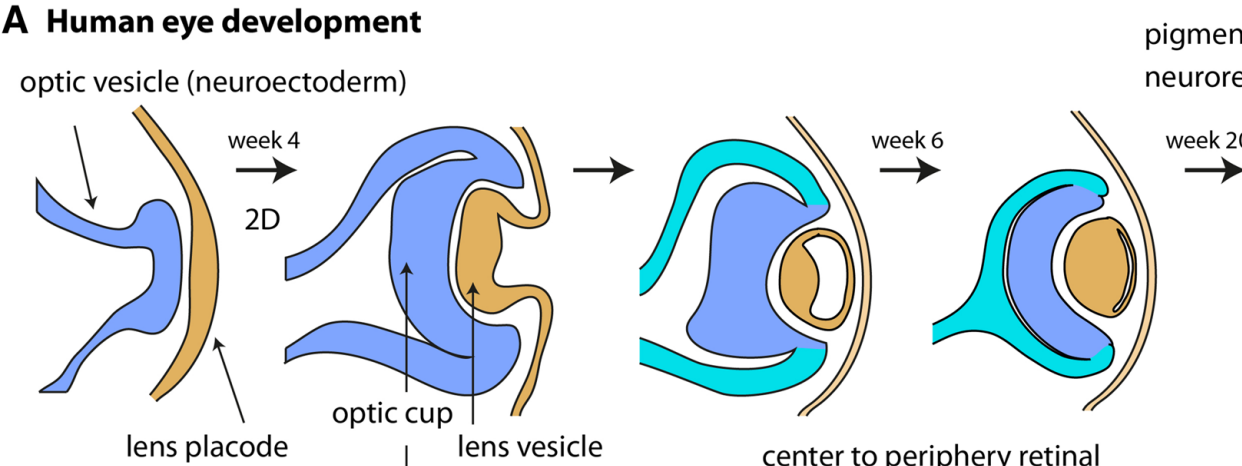

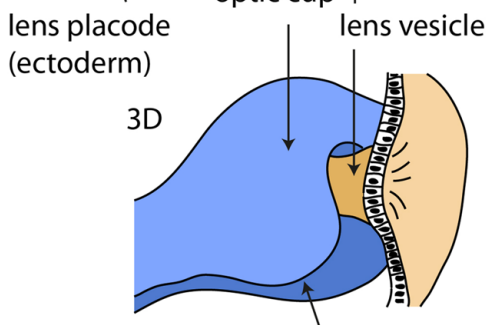

optic fissure

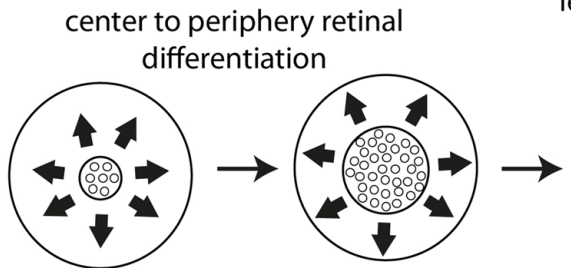

Adult retina patter

\section{B Drosophila eye development}

rod $\mathrm{S}$-cone L-cone $\mathrm{M}$-cone

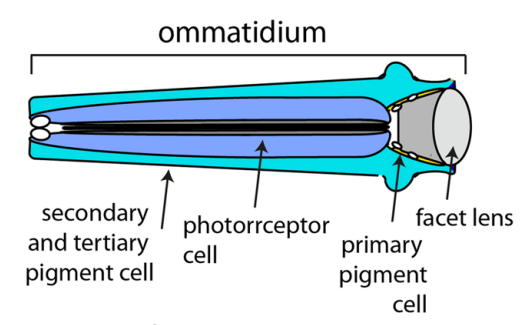

morphogenetic posterior to anterior furrow retinal differentiation

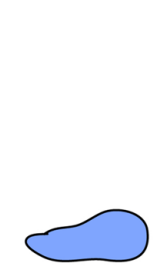

1 st instar eye-antenna disc (derived from invagination of embryonic ectoderm)

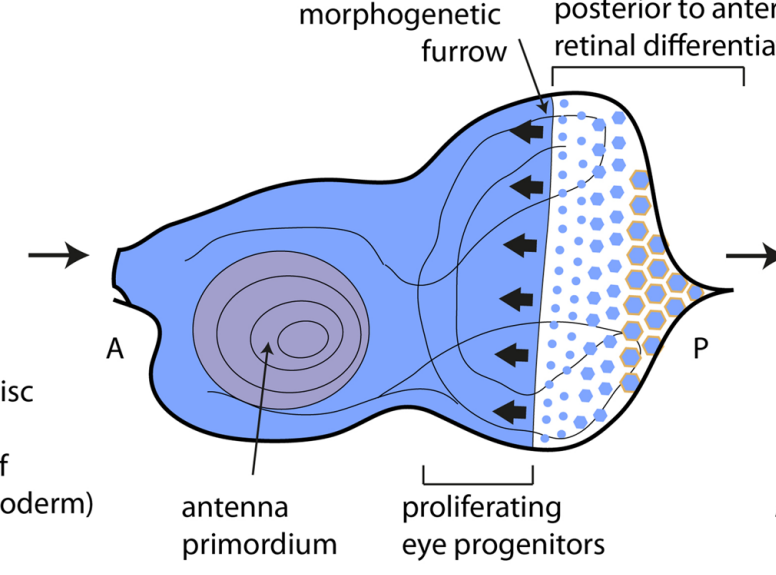

3rd instar eye-antenna disc

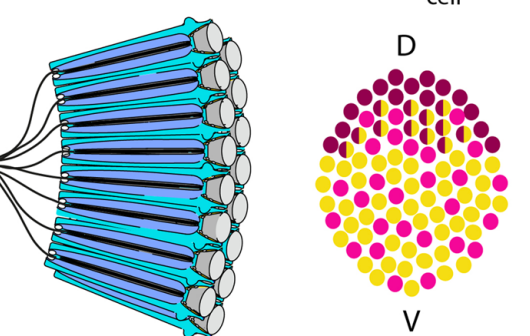

Adult compound eye Adult retina pattern

- dorsal rim area onmatidia (R7-Rh3, R8-Rh3) dorsal yellow ommatidia (R7-Rh3 + Rh4, R8-Rh6) pale ommatidia (R7-Rh3, R8-Rh5)

yellow ommatidia (R7-Rh4, R8-Rh6) 


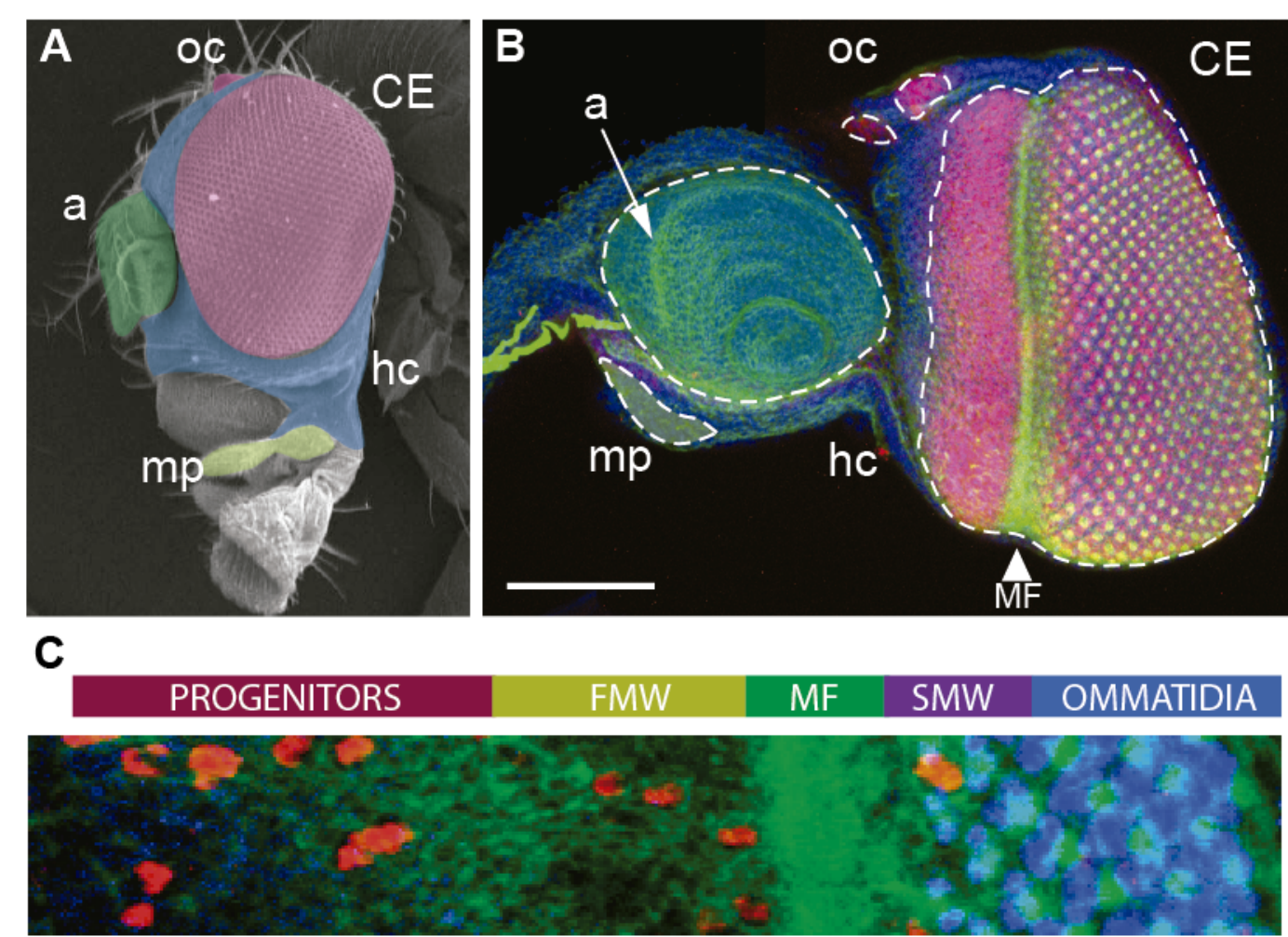

PROLIFERATION DETERMINATION SPECIFICATION

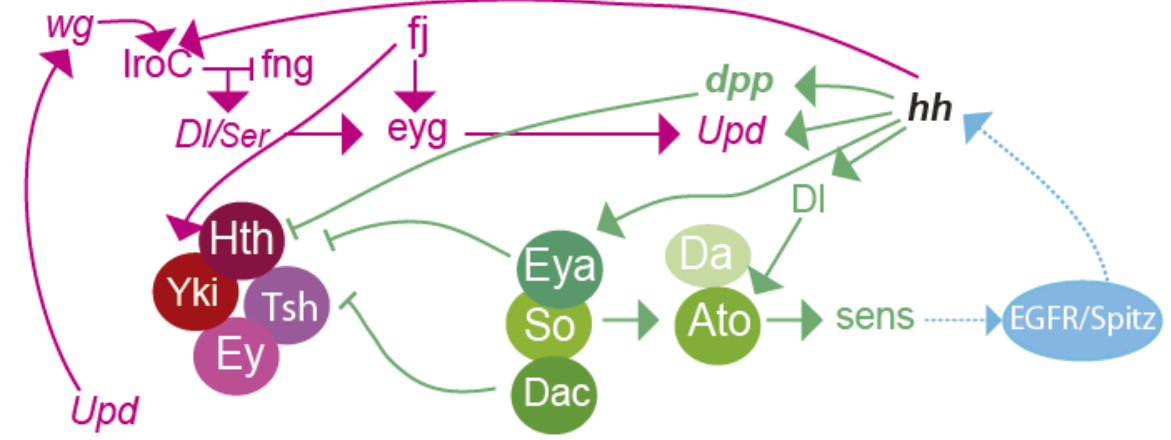



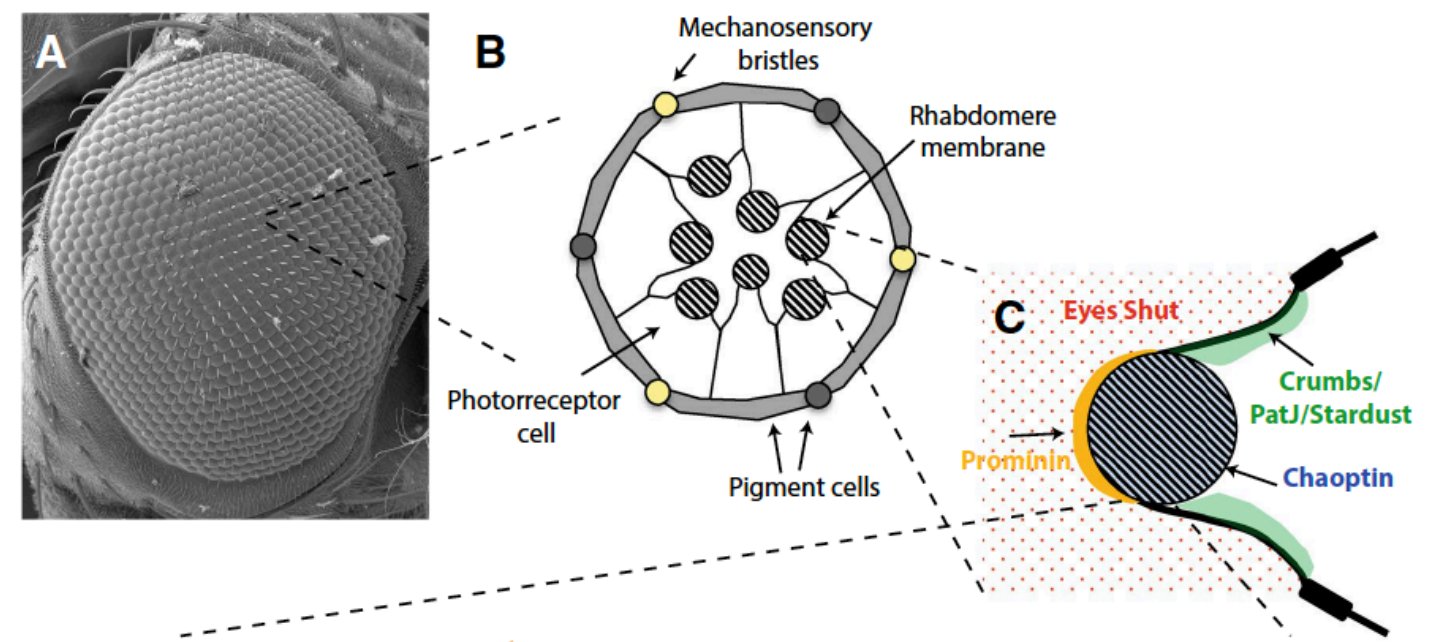

D $480 \mathrm{~nm}$

$580 \mathrm{~nm}$

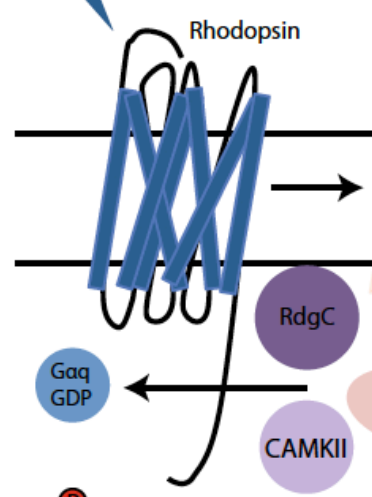

Metarhodopsin

$\mathrm{Na}^{+}$

$\mathrm{Na}^{+}$

$\cap_{n}^{\text {met }}$ $?^{n} f$ TrRP $_{\text {Thabdomee }}$

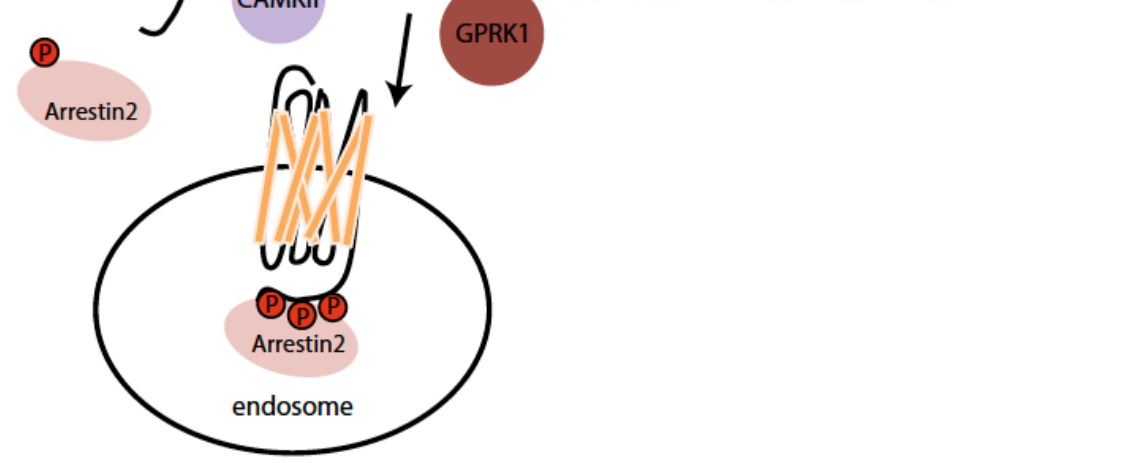

